\title{
Preliminary Overview of Three Purpose-Built Capital Spatial Plans Related to Indonesian Capital Relocation Plan
}

\author{
Hitapriya Suprayitno ${ }^{1, a)}$, Abd Muluk bin Abd Manan ${ }^{2, b)}$ \& Tri Mulyani Sunarharum ${ }^{3, c)}$ \\ ${ }^{1)}$ Department of Civil Engineering, Institut Teknologi Sepuluh Nopember (ITS), Surabaya, Indonesia \\ ${ }^{2)}$ Department of Architecture and Sustainable Development, Universiti Teuku Abdul Rahman (UTAR), \\ Petaling Jaya, Malaysia. \\ ${ }^{2)}$ Department of Architecture \& Planning, Universitas Gajah Mada (UGM), Yogyakarta, Indonesia. \\ Correspondent : ${ }^{a)}$ suprayitno.hita@gmail.com, ${ }^{b)}$ abdmuluk@utar.edu.my \& \\ ${ }^{c)}$ yuni.sunarharum@ugm.ac.id
}

\begin{abstract}
Indonesia has a program to relocate its capital from Jakarta to East Kalimantan Province. This is a big and complex problem and is very interesting for Infrastructure \& Facility Asset Management. Develop reflection on the case is very good to enrich and to develop IFAM knowledge and science. The first step has been done by developing an overview of several capital relocation cases. This research, the second step, is designated to make observations on the spatial plan of three good capitals. Visiting experience of the authors, enriched by literature study has been conducted. The reseach has main conclusions. It is better to develop a new city on an empty inhabited area. The symbolic aspect of the city is very important. A good plan, development, and control must be applied. The city must be green and intelligent. The capital must be divided into core areas for accomodating government offices and the peripheral area for accomodating residential areas and recreational areas. Well designed vast enough open space and several green parks are needed. The whole city must be furnished with good urban public transport. A good domestic and international accessibility is capital.
\end{abstract}

Keywords : infrastructure \& facility asset management, national capital spatial plan

\section{INTRODUCTION}

Indonesia has a program to relocate its capital out of Jakarta. This program has been declared formally by President Joko Widodo on 26 August 2019. The new capital will be located somewhere in two regencies, Penajam Paser Utara Regency and Kutai Kertanegaa Regency, in East Kalimantan Province. The new capital is planned to be used started in the year 2024. The principal reasons to relocate are: the burden on Jakarta is already too high, as well as the burden on the island of Jawa. Why in East Kalimantan is chosen, it is because (1) risk of natural hazards is minimum, (2) located in the center of Indonesia, (3) closed to the developing urban area: Samarinda and Balikpapan, (4) having a relatively complete infrastructure, and (5) the availability of empty land 180 ha. It has been calculated that this program needs budgeting of Rp. 466 trillion, and 19\% of this amount will be financed by National Revenue Expenditure Budget (NREB - APBN), and the rest will be gotten from Public-Private Partnership (PPP) (Abd Manan \& Suprayitno, 2020; Asmara, 2019). Due to Covid19 Pandemic, this program is slowed down, temporarily.

Relocating the capital is a very big and complex program. In general, It deals with preparing a new capital city and take care of the abandoned facilities. It deals with a lot of scientific domains. It is an excellent project and laboratory, based on it, various scientific 
branches can develop their knowledge and science. For urban planning, architecture, civil and environmental engineering, capital relocation can be their very excellent exercise. Certainly, it is also for the field of management, finance, and economics. The other different fields can get an advantage from it also.

Accordingly, the Infrastructure and Facility Asset Management (IFAM) field must think very fortunate to have a major case, based on what the IFAM can enrich their knowledge and science. The program deals with managing the new Infrastructure \& Facilities (I\&F) in new capital and managing the abandoned facilities to be still very useful for capital relocation at least financially. This program is very rich with IFAM cases to be explored. It has cases on each of the I\&F life cycle steps, from idea, planning, pra design, feasibility study, design, construction, operation, maintenance, evaluation, to liquidation. It covers all aspects of IFAM, such as the policy, the economy, the financial, the planning, the design, the engineering, the sustainability, and the others (Abd Manan \& Suprayitno, 2020; Soemitro \& Suprayitno, 2018; Suprayitno \& Soemitro, 2018).

The first step toward using the Indonesia Capital Relocation (ICR) case for enriching the IFAM knowledge and science has been done. It is started by developing a preliminary reflection on the capital relocation phenomena. This gave the main conclusion that capital relocation is not an in-appropriate program. But several cases must be considered as fail programs and the other as a successful program. (Abd Manan \& Suprayitno, 2020) These first step needs to be deepened by observing the spatial plan of the good purpose-plan capital city.

This paper presents the result of preliminary observation of three spatial plans of the three purpose-planned and purpose-built capitals on the inhabited area. The observed capitals are Putrajaya, Canberra, and Washington DC.

\section{RESEARCH METHOD}

This small research is part of an overall objective to develop and to write a scientific systematic reflection for capital relocation. This overall objective can only be achieved through step by step researches and reflections. The first step is to understand capital relocation phenomena, whether it is a common or in-appropriate program, what are the reasons, is there any which can be considered as successful or failure. It has been done. The second step, this small research, is to try to understand the spatial plan of the purpose-built capital, the good examples, and the not too good example.

This small research is designated to make an overview of the capital function, activity, and thus the spatial plan, and main consideration to have such spatial plan. The research, as desktop research, is based on a descriptive analysis based on secondary data, and researcher personal experience to visit and observe the city. The information collected is added with a certain interview with the person knowing the case.

\section{PRELIMINARY OVERVIEW OF THREE CAPITAL SPATIAL PLANS}

\section{Previous Work and Discussion Systematic}

The previous work is a preliminary overview of capital relocation cases. It has been noted that capital relocation is common and is not in-appropriate, and it has been started since a longtime ago. Common reasons for capital relocation are the old capital was too dense, looking for a more central location, establishing a capital in federal territory, balancing development, military reason. Certain capital relocations can be considered as a success if the city is well planned and well-controlled, well-organized development, no industry, so the city land-use and density are still controlled. The others should be considered as a failure, in case the city density cannot be controlled, as it is located adjacent to the existing city, not well planned, not well 
controlled. This caused industry development, high-density urban area, traffic jam, and pollution (Abd Manan \& Suprayitno, 2020).

This paper, as a continuation of the previous reflection, is designated to observe good examples of capital spatial plan. The discussion is arranged started by a list of purpose-built new capitals, followed by identifying capitals with a good spatial plan, continued by observing three capital spatial plans, and ended by main conclusions.

\section{Purpose-Planned New Capital City}

During the $20^{\text {th }}$ and the $21^{\text {st }}$ centuries, there are 15 purpose-built capital relocations. Added with Washington DC started to be used in 1800, there are, at least, 16 purpose-built new capitals (Wikipedia, 2020). Those 16 capitals are presented in Table 1 as follows.

Table 1. List of 16 Capital Relocation Examples

\begin{tabular}{|c|l|l|c|}
\hline No & City & Country & Year \\
\hline 1 & Washington DC & USA & 1800 \\
\hline 2 & New Delhi & India & 1912 \\
\hline 3 & Canberra & Australia & 1913 \\
\hline 4 & Ankara & Turkey & 1923 \\
\hline 5 & Quezon City & Philippines & 1948 \\
\hline 6 & Nuakchott & Mauritinia & 1958 \\
\hline 7 & Brasilia & Brazil & 1960 \\
\hline 8 & Islamabad & Pakistan & 1960 \\
\hline 9 & Gaborone & Botswana & 1964 \\
\hline 10 & Belmopan & Belize & 1970 \\
\hline 11 & Palikir & Micronesia & 1989 \\
\hline 12 & Abuja & Nigeria & 1991 \\
\hline 13 & Nur-Sultan & Kazakhstan & 1998 \\
\hline 14 & Putrajaya & Malaysia & 2002 \\
\hline 15 & Naypyidaw & Myanmar & 2005 \\
\hline 16 & Ngerulmud & Palau & 2006 \\
\hline source $:$ Wikipedia, 2020 & & \\
\hline
\end{tabular}

Among those 16 purpose-built capitals, we have to note Washington DC, Canberra, Brasilia, Nur-Sultan, Putrajaya and Naypyidaw are the big capital city with good spatial plans. Due to the researcher's knowledge and experiences, three pertinent Capital Spatial Plans are observed here, i.e. Putrajaya, Canberra, and Washington DC.

\section{Putrajaya (Malaysia)}

\section{The Creation}

The former capital of Malaysia is Kuala Lumpur. The idea to relocate the capital was thought started in the late 1980s, during the first tenure of the fourth Prime Minister Mahathir Mohamad. The basic idea is to relocate the capital between Kuala Lumpur and Kuala Lumpur International Airport (KLIA). Two alternatives were thought, i.e. in Prang Besar in Selangor and Janda Baik in Pahang (Ho, 2016; Kaur, 2019; Wikipedia, 2020a).

The discussion with Selangor was held in the early 1990s. An area of $49 \mathrm{~km} 2$, part of Sepang District, in Selangor, was chosen. This is about $25 \mathrm{~km}$ south of Kuala Lumpur. The plan to move was established on 19 Oct 1995. Finally, in 1999 the Federal Government was moved from Kuala Lumpur. The capital is named after Teuku Abdurachman Putra Al-Haj, the First Prime Minister. On 1 February 2001, Putrajaya was awarded as Federal Territory, following the two federal territories, i.e. Kuala Lumpur on 1 February 1974, and Labuan Island in Sarawak 
in April 1984. The seat of the King, the Parliament, and Foreign Embassies are still in Kuala Lumpur (Ho, 2016; Moser, 2010; Wikipedia, 2020a). Putrajaya Location Map is presented in Figure 1.

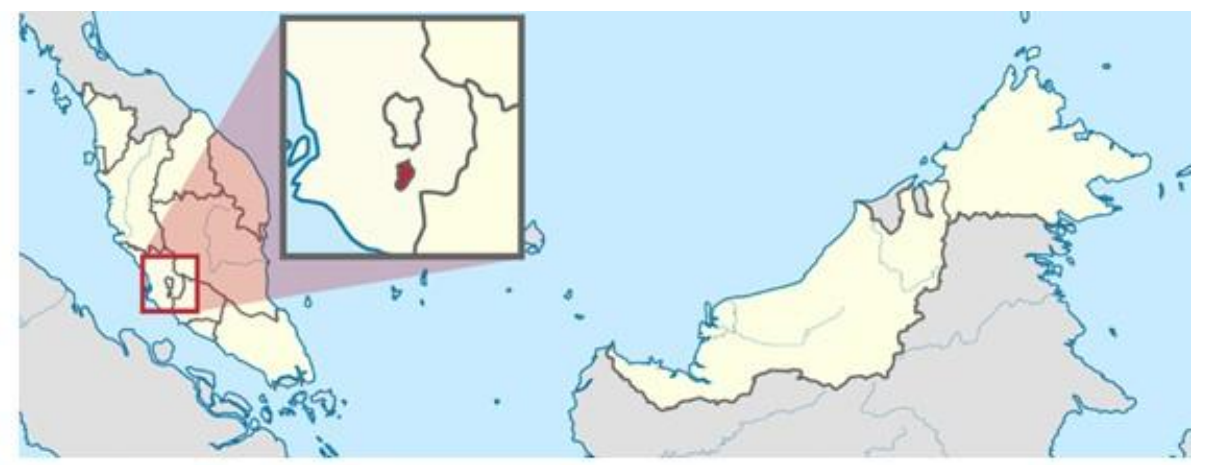

Source : Wikipedia

Figure 1. Putrajaya Location Map

The City Main Function and Activity

In an area of $49 \mathrm{sqkm}$, Putrajaya was created to execute its main function as the seat of the Federal Government, only for the Executive and the Judicatif. The seat of the King and the Parliament remains in Kuala Lumpur. Kuala Lumpur is still considered as National Capital, Commercial Center, and Financial Center (Moser, 2010; Putrajaya Corporation, 2012; Wikipedia, 2020a).

Besides, it holds secondary function as a venue for an international convention, international sport and cultural events, and tourism. Putrajaya is also created as Garden City and Intelligent City to cope with the new future tendency (Ho, 2016; Kaur, 2019; Moser, 2010; Wikipedia, 2020a).

Therefore, the main activities in Putrajaya are government-related activity, international convention, cultural, tourism, and sports events. It is the venue for high profile events, such as international conference, international hot air balloon, flower carnival, Tour de Langkawi, international waterski championship. There is no high commercial and industrial activity here (Kaur, 2019; Putrajaya Corporation, 2012; Wikipedia, 2020a).

The management of Putrajaya is commissioned to Perbadanan Putrajaya, in English this is called as Putrajaya Corporation, a local authority to manage Putrajaya City (Putrajaya Corporation, 2012; Wikipedia, 2020a).

\section{The Spatial Plan}

The Putrajaya spatial plan is presented in several parts: i.e. the General Concept, the General Spatial Plan arrangement, the Core Area and the Government Axis, the Peripheral Area, the Open Space, and the Green Park, the Landmarks, the General Transport Accessibility, and the Urban Public Transport.

As the seat of the Federal Government, Putrajaya is designed as a Garden City and an Intelligent City. Therefore, Putrajaya is included in the MSC (Multimedia Super Corridor), the Malaysian Silicon Valey. The MSC stretch between Kuala Lumpur and KLIA, it covers an area of $15 \times 50 \mathrm{~km}(750 \mathrm{~km} 2)$, and pass through Cyberjaya and Putrajaya. Cyberjaya is a city next to the west of Putrajaya. Putrajaya is furnished with an artificial lake Putra Lake in the middle, stretch in the north-south direction. Putrajaya is planned to accommodate more than 335,000 people, on an area of 4,400 ha. In 2018 data, the total Putrajaya covers an area of 49 sqkm, with an inhabitant of 891,908, and had a very high Human Development Index (HDI) of around 0.85 (Ho, 2016; Wikipedia, 2020a).

In general, Putrajaya is divided into 20 precincts and 1 diplomatic precinct. Putra Lake, an artificial lake stretching north-south, with artificial river Semenyih half circling in the south. 
The whole Putrajaya is divided into the core area (Precinct 1-5) and the peripheral area (Precinct 6-20). The total area is divided, approximately, for Open Space \& Green Area at 37.8\%, for Residential Area at $25.5 \%$, for Infrastructures at $18.8 \%$, for Utilities at $4.6 \%$, for Government Office at $5.3 \%$, for Public Facilities at $9.7 \%$, and Commercial Area at 2.5\%. The core area, 5 precincts, is destined for the government offices, national and international facilities, and activity centers. The peripheral area, 16 precincts, surrounding the core area is destined for housing and community facility. Precinct 1 functions as the center of the whole Putrajaya, where Putra Square, Prime Minister Office, and Putra Mosque are located. The Prime Minister's official residence is located in Precinct 10, on the other side of the lake from the Prime Minister Office (Ho, 2016; Moser, 2010; Omar, 2004; Wikipedia, 2020a). Putrajaya's precinct's general arrangement is presented in Figure 2.
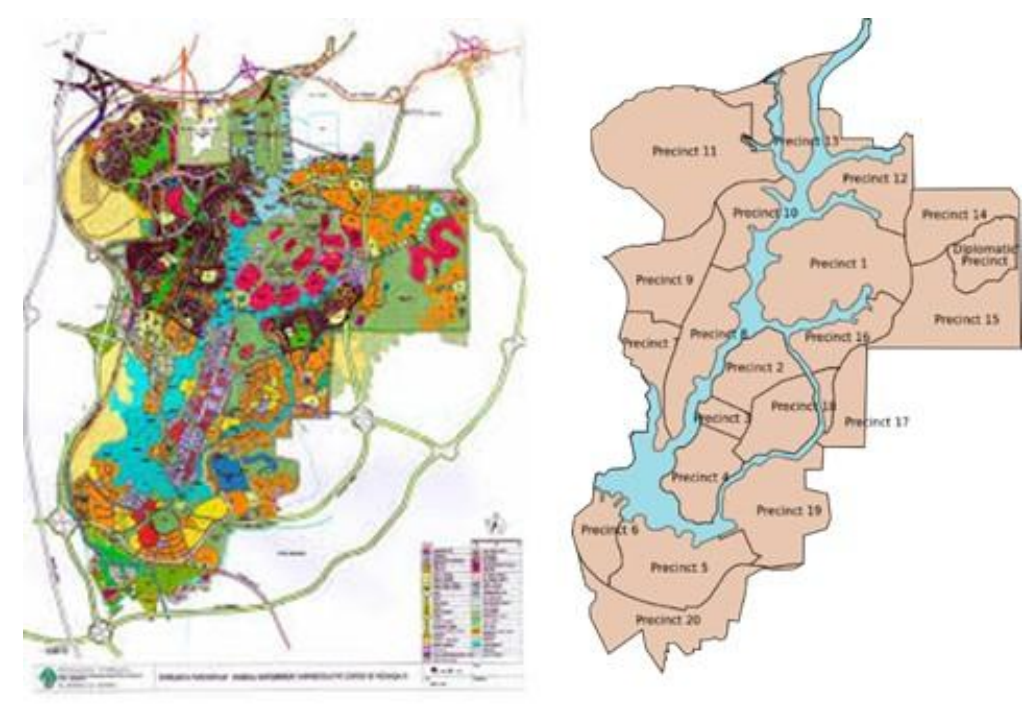

Source : Wikipedia

Figure 2. Putrajaya Percincts General Arrangement

It has been mentioned that the Core Area, for locating the government offices, covers the Precinct 1 to Precinct 5. Among these 5 precincts, Precinct 1 is designated for the Head of the Federal Government with Putrajaya Botanical Garden and Putra Perdana on the northern part and Alamanda Comercial Center on the north-west part of the Precinct 1. The Precinct 5 is destined to hold the convention center, the university, and others. While Precincts 2-4 are destined to accommodate all of the governmental offices. The center of the whole Putrajaya is the Putra Square, with Putra Mosque in the west and the Prime Minister Office in the north. From the Prime Minister Office, there is a straight boulevard, stretching $4.2 \mathrm{~km}$ to the south down to Precinct 5, where Putrajaya International Convention Center (PICC) is located. It forms an axis north-south (central spinal). on-which all of the Government Offices are located, and it is called Persiaran Perdana. The boulevard pass through Putra Bridge and Seri Gemilang Bridge. Two universities are located in Putrajaya, i.e. Puspahanas (Defence University) in Precinct 1 and Hariot-Watt University in Precinct 5. This is the main governmental axis in Putrajaya (Ho, 2016; Moser, 2010, Omar, 2004; Wikipedia, 2020a). Putrajaya Core Area is presented in Figure 3. 


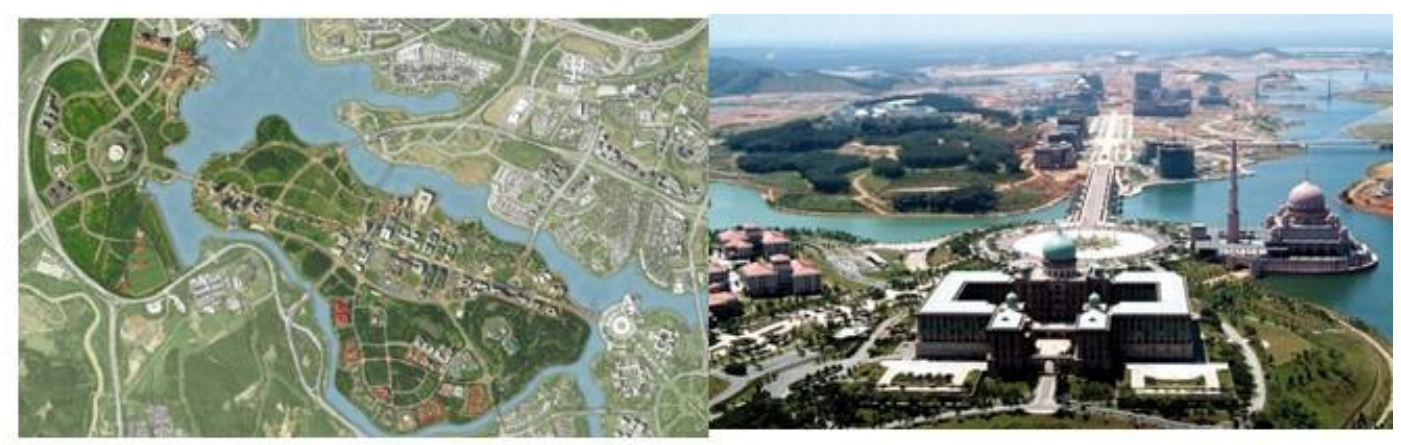

Source : Wikipedia

Figure 3. Putrajaya Core Area Precincts 1-5

Peripheral area, covering Precincts 6-20, is designated for housing, parks \& open space, community facilities, and recreation. The peripheral area is on the other side of Putra Lake compared to the Core Area. The precinct numbering follows clockwise, started from Precinct 1 south-wise until it reaches Prercint 5, from here numbering turn west started from precinct 6 . Each Precinct is well equipped with health clinics, schools, police stations, open space, gardens, social facilities, food stall and restaurant, grocery markets, bus stops, and taxi stands (Ho, 2016; Moser, 2010, Omar, 2004; Wikipedia, 2020a).

The main objects of certain peripheral precincts are mentioned as follows. Precinct 6 is furnished with Kompleks Sukan Air and Putrajaya Recreational Airstrip. Precinct 7 is the location of Putrajaya Train Station, Putrajaya Hospital, City Bus Terminal, Putrajaya District Police Head Quarter, and Fire and Rescue Station. Precinct 8 is dominated by Istana Darul Ehsan. Precinct 9 is the location of Kompleks Kejiranan. Precinct 10 is dominated by Seri Perdana Complex, Prime Minister Official Resident. Precinct 11 is dominated by Kompleks Kejiranan, Taman Saujana Hijau, and Perbadanan Putrajaya. Precinct 13 is dominated by Putrajaya Wetland. Precinct 15 is dominated by Museum Semula Jadi, Rimba Raya Park, and Diplomatic Precinct. Precinct 16 is furnished by Shafty Shopping Center and Everly Hotel. Precinct 19 is where Water Treatment Sungai Semenyih and Equestrian Park are located. Precinct 20, in the south end of Putrajaya, is the place for National Cemetery, Muslim Cemetery, Crematorium, and Taman Selatan (Omar, 2004; Wikipedia, 2020a). The map of Putrajaya Peripheral precincts is presented in Figure 4.
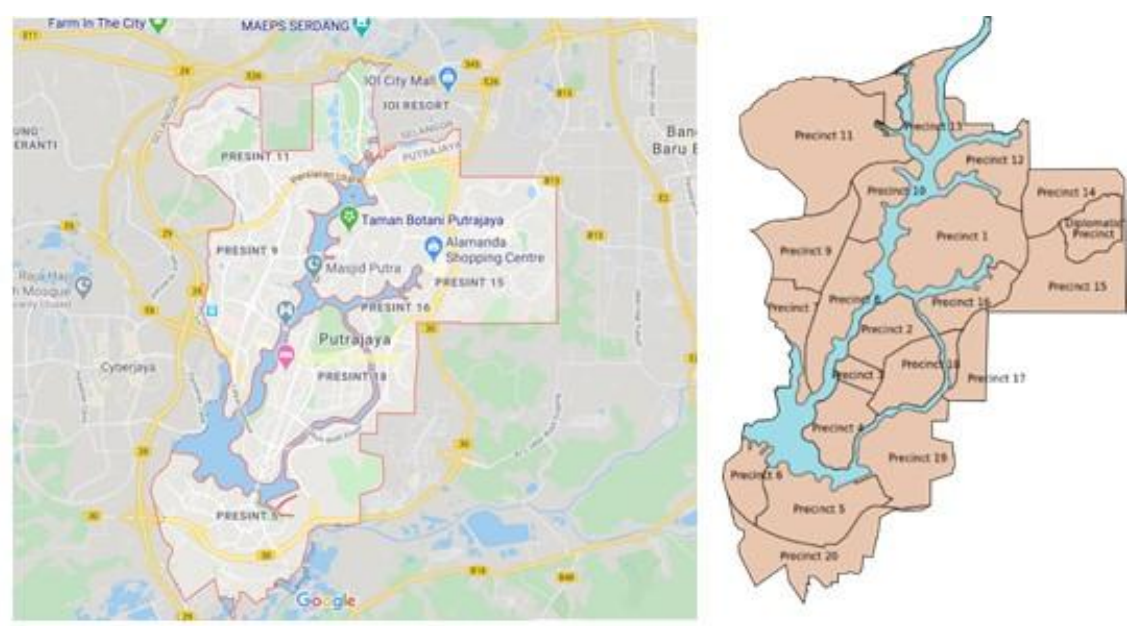

Source : Wikipedia

Figure 4. Putrajaya Peripheral Precincts

Putrajaya is developed with abundant Open Spaces and Green Parks. The main Open Space consists of Putrajaya Lake, Putra Square, and Perdana Hill. While the Green Park consists 
of Putrajaya Botanical Garden, Putra Perdana Park, Putrajaya Wetland, Sajunjungan Park, Wawasan Park, Agricultural Heritage Park, Rimba Raya Park, and Taman Selatan. Apart from these big Green Parks, small green facilities can be found everywhere along all of the main roads, special green corners, green residential areas, and along each side of water bodies (Moser, 2010; Putrajaya Corporation, 2012; Wikipedia, 2020a). The map and photos of the Green Parks are presented in Figure 5.

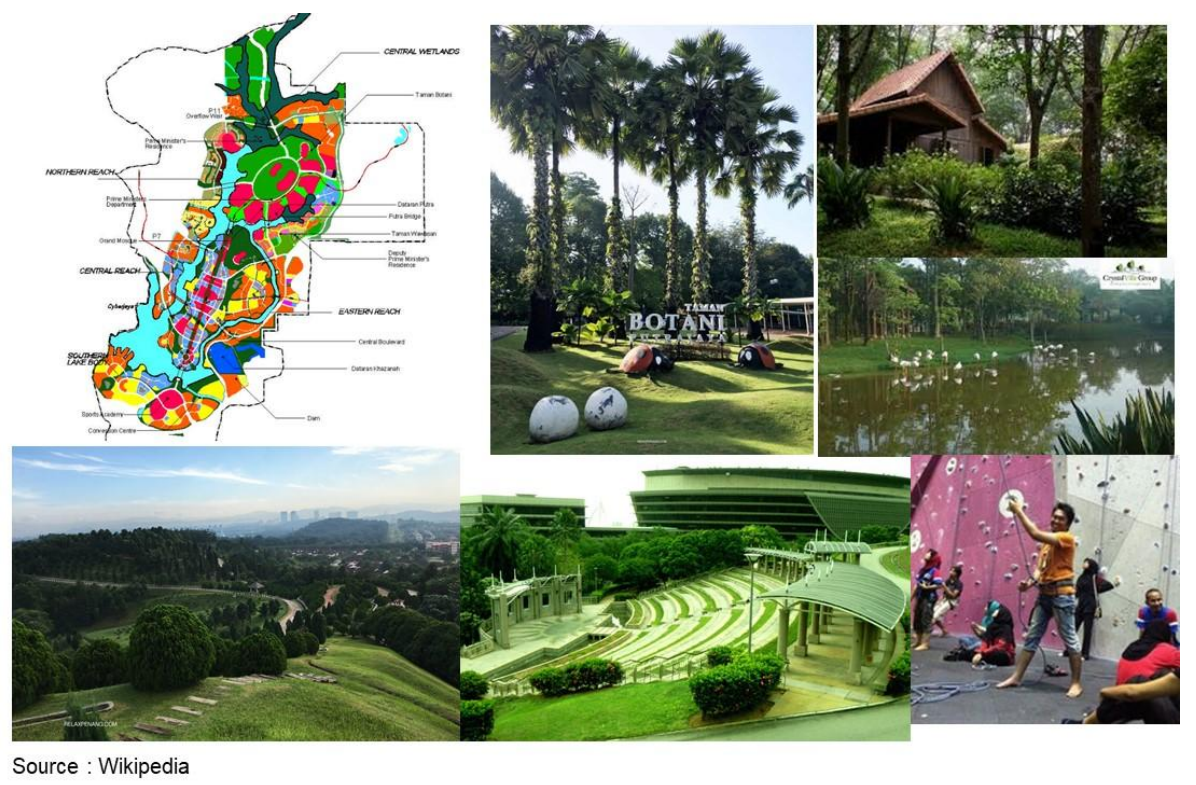

Figure 5. Putrajaya Open Space and Green Park

Landmark is always important for National Capital City. The most important landmark in Putrajaya, even this is not well known, is Mercu Tanda Putrajaya. The Mercu is located on the peak of Putra Perdana Hill, and it is the first construction to be built, as a sign of the construction start of Putrajaya. The other main landmarks are Putra Lake, Putra Square, Putra Mosque, Prime Minister Office, Mercu Millenium, Seri Wawasan Bridge, and also Putrajaya International Convention Center (PICC), these all are man-made landmarks (Omar, 2004; Wikipedia, 2020a). Putrajaya Main Landmarks is presented in Figure 6.

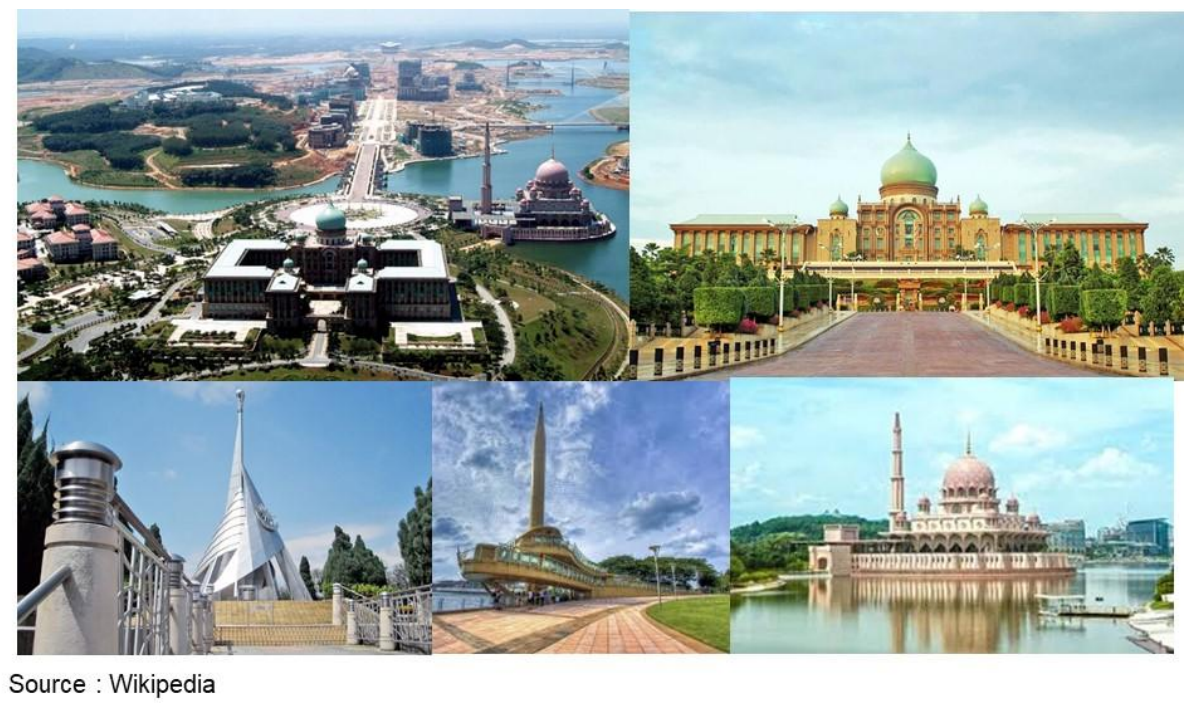

Figure 6. Putrajaya Main Landmarks

As the seat for the Federal Government, Putrajaya must be well connected to the main international and national destinations, by road transportation, railway transportation, and air transportation. There is no industrial transportation inside, to and from Putrajaya. 
As the connection to the exterior, Putrajaya, in its vicinity, is well-surrounded expressways, by North-South Central Link KLIA Expressway (AH2/E6) in the west, E2 Expressway (North-South Expressway) connecting Kuala Lumpur - Seremban in the east, SKVE E26 Expressway (South Klang Valley Expressway) in the north, the AH2 run toward the east in the south of Putrajaya to meet E2 Expressway in the south-east of Putrajaya. Putrajaya can also be reached from Kuala Lumpur by using MEX E20 Expressway (Maju Expressway), connecting Kuala Lumpur to Cyberjaya. The AH2 Expressway (E6 Expressway) has an expressway branching to Putrajaya and Cyberjaya, called E6 Putrajaya Link. The E6 junction is located in the south of Bandar Nusa Putra. The KLIA can be reached from Putrajaya, by using AH2 Expressway, continued by E6 Expressway. In terms of Railway connection, Putrajaya is directly connected to Central Station Kuala Lumpur and KLIA by KLIA Railway. Putrajaya is also served by Intercity Bus operated by 3 different companies (Ho, 2016; Ho, 2016a; Putrajaya Corporation, 2012; Wikipedia, 2020a). This Putrajaya General Transport Accessibility is presented in Figure 7.

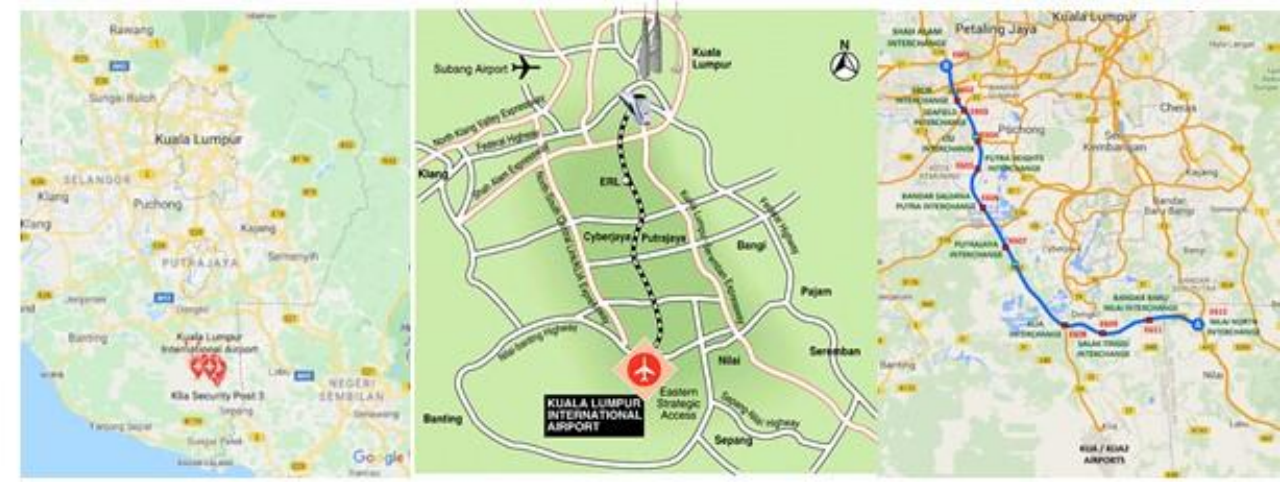

Source : Wikipedia

Figure 7. Putrajaya General Transport Accessibility

In 2020, the urban transport in Putrajaya is supported by a good road network, city bus network, and taxi services. The Putrajaya main road network is presented in Figure 10.

Discussing the Putrajaya road network, it is organized on several levels, the expressway, the federal highway, the Putrajaya highway, and the main local road. Accessing a certain destination in Putrajaya from outside must be started by passing through the expressway, then continued by following the corresponding highways to achieve the corresponding main precinct road. It has been mentioned that the expressways in the vicinity are the E2, the E6, the E26, and the E20. From these expressways, we can continue through the federal highway, i.e. the H29 Pesiaran Barat, H30 Pesiaran Timur, and Pesiaran Utara. And then, accessing the Precinct Main Road must be done through the main municipal highway, i.e. Lebuh Sentosa, Lebuh Wadi Ehsan, Persiaran Utara, Persiaran Persekutuan, Perdana Putra Park Ring Road, Lebuh Perdana Selatan, Lebuh Perdana Timur, Lebuh Perdana Barat, Persiaran Perdana, Lebuh Bestari, Lebuh Wawasan, Lebuh Gemilang. For these highways, we can enter the Precinct Main Road to achieve the destination in each precinct. All of the expressway and federal highway are all limited-access road (Putrajaya Corporation 2012; Wikipedia, 2020a).

Putrajaya City Bus, Nadi Putra, serve well each precinct. All of the Main Precinct Roads are served by the city bus. At all, it has 7 regular bus lines and 8 night-bus lines; and all City Bus terminus is concentrated closed in front of Putrajaya Train Station. Special bus lanes are implemented on certain roads. Taxi stands are well distributed all over the area, all of the precinct central area (Nor \& Nor, 2006; Putrajaya Corporation, 2012; Wikipedia, 2020a). The Putrajaya main road network is presented in Figure 8. 

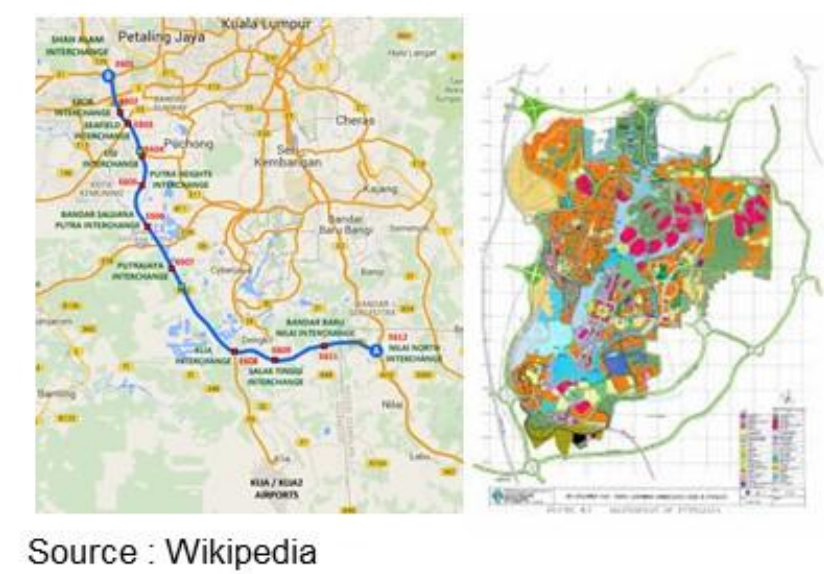

Figure 8. Putrajaya Main Road Network

\section{The Development}

Putrajaya was designed, planned, and constructed by the Malaysian. The site was chosen, in Prang Besar - Sepang in 1993. Right afterward, a consortium to develop a Master Plan was established. Conceptual Master Plan was approved by the Cabinet in April 1994, while the Master Plan was accepted in February 1995. The official launch of the Putrajaya project was done in August 1995. The Putrajaya Development is planned in two phases over 15 years, the first phase in 1996 - 2000, and the second phase in $2000-2010$. The construction is commissioned to Putrajaya Holding. Four main components were built and finished first, i.e. the road network, Putra Perdana Park, Putra Mosque, Prime Minister Office, and Putra Square. The whole construction was estimated at a cost of US \$ 8.1 billion (Ho, 2016; Ho, 2016a; Putrajaya Corporation, 2012; Wikipedia, 2020a).

The primary construction was finished in 1999, and soon the Prime Minister Office was moved first. In the year of 2005, almost all ministries have been moved, except the Ministry of International Trade and Industry, the Ministry of Defence, and the Ministry of Works. In 2019, almost all of the embassy has been moved to Putrajaya. The whole Putrajaya were constructed step-by-step (Kaur 2019; Wikipedia, 2020a).

\section{The Important Notes}

Observations on Putrajaya gave several important aspects to be highlighted. Putrajaya is purpose-planned-developed on an uninhabited piece of land to accommodate the Federal Executive and Judicative Body. It covers only 49 sqkm on a rolling area, designated as Federal Territory, and developed to be an Intelligent City in the Garden. The city is organized into 20 precincts, and the Putralake, an artificial lake covering $6.6 \mathrm{sqkm}$, functions as a very vast Urban Open Space. Precincts 1-5, stretching north-south, as the Core Area of Putrajaya, are designated as a government office area. It started in Precinct 1 to accommodate the Prime Minister Office, Putra Square, Bureau of Economic Planning. The building height restriction is applied in Precinct 1. An ax of wide straight boulevard Pesiaran Perdana connects Prime Minister Office on the north end in Precinct 1 to the PICC in the south end in Precinct 5. All of the Offices of the Ministries are all located along this boulevard, in Percintcts 2, 3, 4. Precinct 5 is equipped with a university and cemetery area. Precincts 6-20, surrounding the Core Area, are designated mainly for residential areas and other main Urban Facilities. Each Peripheral Precinct is well furnished with community infrastructures and facilities. Practically all Landmarks are located in the core area. Putrajaya has 8 different Thematic Green Parks, distributed from north to south. Most of the main Tourism Objects are located in the vicinity of the Putra Lake. The Road Network structure must be noted. It is created on different levels, from the Expressway, Federal Highway, Municipal Highway, Precinct Main Roads., and ended by Local Precinct Road. 
Urban Public Transport is served by taxi and city buses. The city bus network well penetrates down to all of Main Precinct Roads. The industry is prohibited in Putrajaya.

\section{Canberra (Australia)}

\section{The Creation}

The British established its first penal colony in Australia in January 1788, as the first British Fleet arrived in Botany Bay. During the next century, the British expanded the colony throughout Australia, started from the east coast: New South Wales and Queensland. During the last $19^{\text {th }}$ century, among the colonies emerged the idea to create an Autonomous Parliamentary Democracy. A referendum was conducted in establishing a Federal Government. The British Kingdom agreed and Australia is stated as a Member of Commonwealth Countries (Wikipedia, 2020h).

A Federal Capital needs to be created. A concurrence between Sidney - the oldest city and Melbourne - the new more prosperous city. Finally, all of the states agreed to established Australia Capital Territory (ACT) in the South New South Wales, at a distance of $246 \mathrm{~km}$ from Sidney, and 658 from Melbourne. Based on Seat of Government Act 1908, an area of YassCanberra was ceded to the Federal Government. Canberra, the capital, is located inside the ACT, together with several townships (Wikipedia, 2020i). ACT has an area of 2,358 sqkm, consists of 2,280 sqkm of land, and 77,6 sqkm (3.29\%) of water - river, and lake. An international competition was organized to develop a Master Plan of Canberra. Architect Walter Burley Griffin and Marion Mahony Griffin from Chicago won the competition. Location Map of ACT \& Canberra and Original Master Plan by the Griffins are presented in Figure 9.

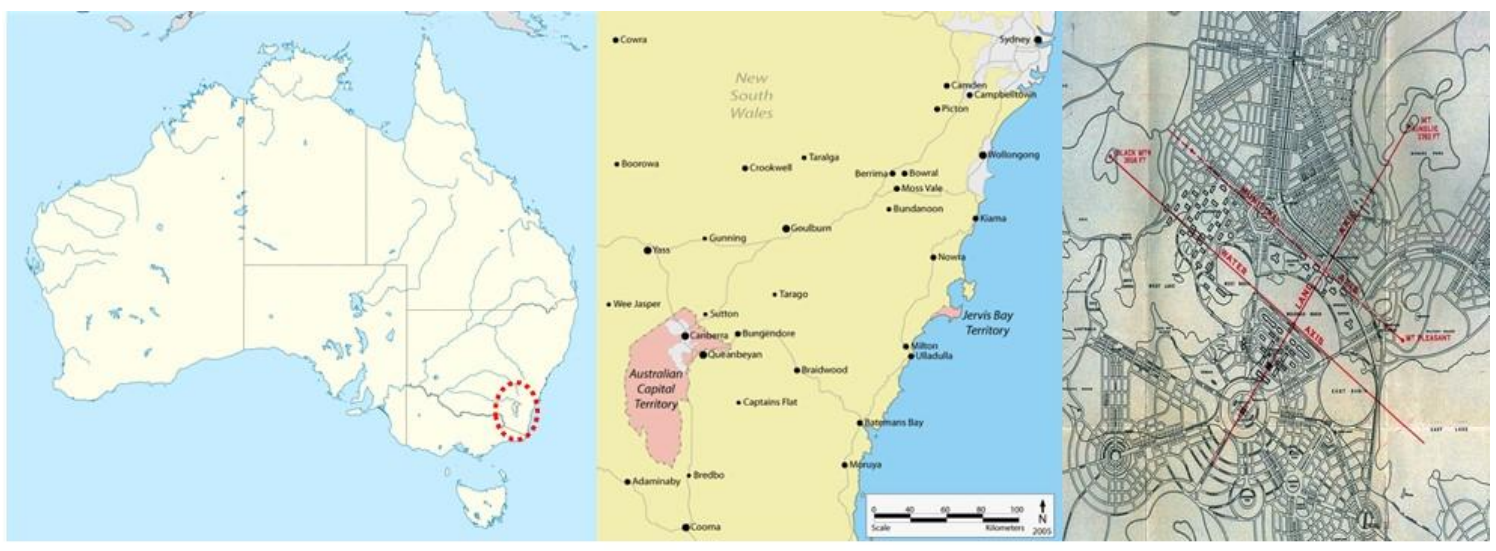

Source : Wikipedia

Figure 9. Location Map of ACT \& Canberra and the Original First Master Plan

The City Main Function and Activity

As part of and located in the ACT, Canberra is planned to be the National Capital. So, its Basic Function is as the Seat of Federal Government, accommodating the federal legislative, executive and judicative institution, other federal government units, the embassies, and important international institutions. Apart from these, Canberra accommodates various national cultural centers, national education center research, national sports center, national military center, and also scientific center. Big industry and big commercial activities are prohibited.

The Spatial Plan

The Spatial Plan is presented in two parts, the ACT and Canberra. The review of the ACT spatial plan, especially, concentrated on the area, the boundary, general land use, forming county, Canberra location, and townships. While the review of Canberra's spatial plan is concentrated on city theme, general spatial plan, core area, peripheral area, open space and 
green area, landmark, cultural center, sports center, higher education, international event, utility, and transportation system.

Australia Capital Territory (ACT) is an area designated for the Federal Territory, in which the City of Canberra as National Capital is located. ACT is formed by former Murray County in the northern part and Cowley County in the southern part. The ACT covers an area of 2.358 sqkm, stretching of about $88.5 \mathrm{~km}$ in the north-south direction, and $57.75 \mathrm{~km}$ in the east-west direction. The whole area consists of a land area of 2,280 sqkm, and a water area of $77.6 \mathrm{sqkm}$ (3.29\%). It is bounded by the Goulburn-Cooma railway line in the northeast, the watershed of Naas Creek in the south, the watershed of Cotter River in the west, the watershed of Molonglo River in the northeast. This area arrangement is established to give enough water supply to ACT. ACT has a lot of Protected Areas, it can be grouped into 3 categories, ie. Namadgi National Park, Australian National Botanic Gardens, and 43 Nature Reserves. It is must be noted that $46 \%$ of the ACT area is covered by Namadgi National Park. It is a large range of mountain, rivers, and creeks which cover most of the southern area of ACT. It was established in 1984, and has an area of 1,060,95 sqkm, at a distance of $40 \mathrm{~km}$ south of Canberra. Bimberi Peak is the highest point at $1.911 \mathrm{~m}$. The water catchment area of the park fulfills $85 \%$ of the water supply to Canberra. On 7 November 2008, the Park is added to the Australian National Heritage List, thus very protected. The ACT has agricultural areas fill with sheep farms, dairy cattle farms, vineyards, and small crops. Out of the Namadgi National Park and due to the District Act 1966, the ACT administratively is divided into 16 districts. The city of Canberra is located in the northern tip of ACT. Several townships can be mentioned such as Williamsdale, Naas, Uriarra, Tharwa, and Hall (Wikipedia, 2020j; Wikipedia, 2020k; Wikipedia, 20201; Wikipedia, 2020m). The Map of ACT, Namadgi National Park, and Satellite Image of Canberra are presented in Figure 10.
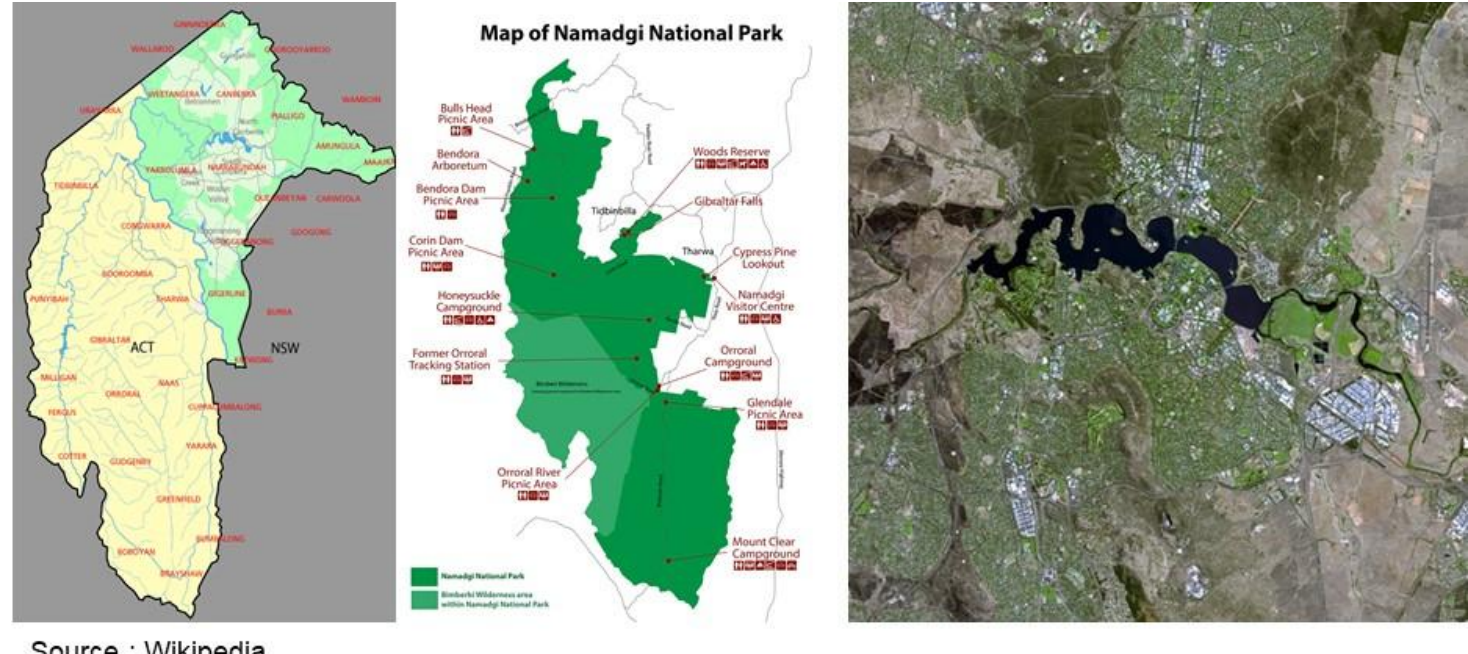

Figure 10. Map of ACT, Namadgi National Park, and Satellite Image of Canberra

Canberra, by the Griffins, was planned and design as a Garden City. Having an area of $814.2 \mathrm{sqkm}$, with a population of 426,704 in 2019, Canberra has a population density of 504 people/sqkm. It is located $248 \mathrm{~km}$ south of Sidney and $654 \mathrm{~km}$ north of Melbourne. Canberra lies on an undulating hilly area.

Among the 16 Districts of ACT, 7 of them are part of Canberra City. These consist of the Districts of North Canberra, South Canberra, Woden, Belconnen, Weston Creek, Tuggeranong, and Gungahlin. Those 7 districts do not form a compact area, but these are rather spread southnorth (Wikipedia, 2020n). The Map of Canberra Districts is presented in Figure 11 as follows. 


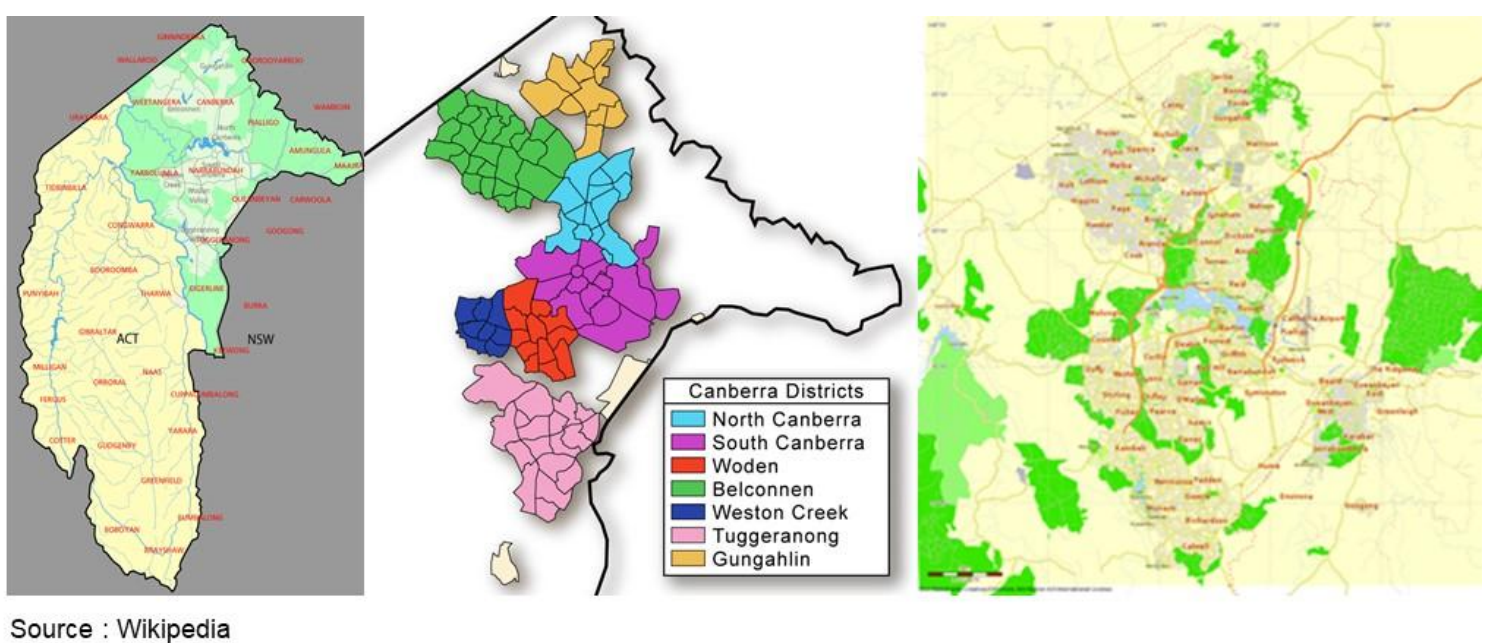

Figure 11. Map of Canberra Districts

General Spatial Plan. Very irregular area form, because of the existence of Nature Reserve and Parks. Irregular road patterns. Divided into two areas, i.e. the core and the residential. The core area is designated for the government office, institution building, the embassy, the museum, etc. The residential area spread around the core area. The core area covers the districts of North Canberra and the South Canberra. While the 5 other districts are designated mainly for the residential area. Lake Burley Griffin and Nature Reserve pose as open spaces and green areas.

The Core Area is located around the Parliament Triangle in the districts of North Canberra and South Canberra, often called as the Civic. The triangle is formed by Convention Avenue in the north-east, the King Avenue in the east-south, and the Commonwealth avenue stretching north-south in the west. The Convention Avenue form as the triangle base. South of the triangle base is filled with West Lake Burley Griffin. The triangle peak, in the southern tip, is filled with Circle Concentric Road Network, in which the Federal Institution Buildings are located. The center of the concentric is filled with the Parliament Building. While it's surrounding, in the circle road network is filled with different Government Offices, the Embassies, and the International Institutions. The south of the lake area is filled with parks, in which the High Court Office, several national important Museums and Galleries are located. The train station and the Canberra International Airport are located in the South Canberra district (Wikipedia, 2020b; Wikipedia, 2020n). The map of Parliament Triangle is presented in Figure 12 as follows. 


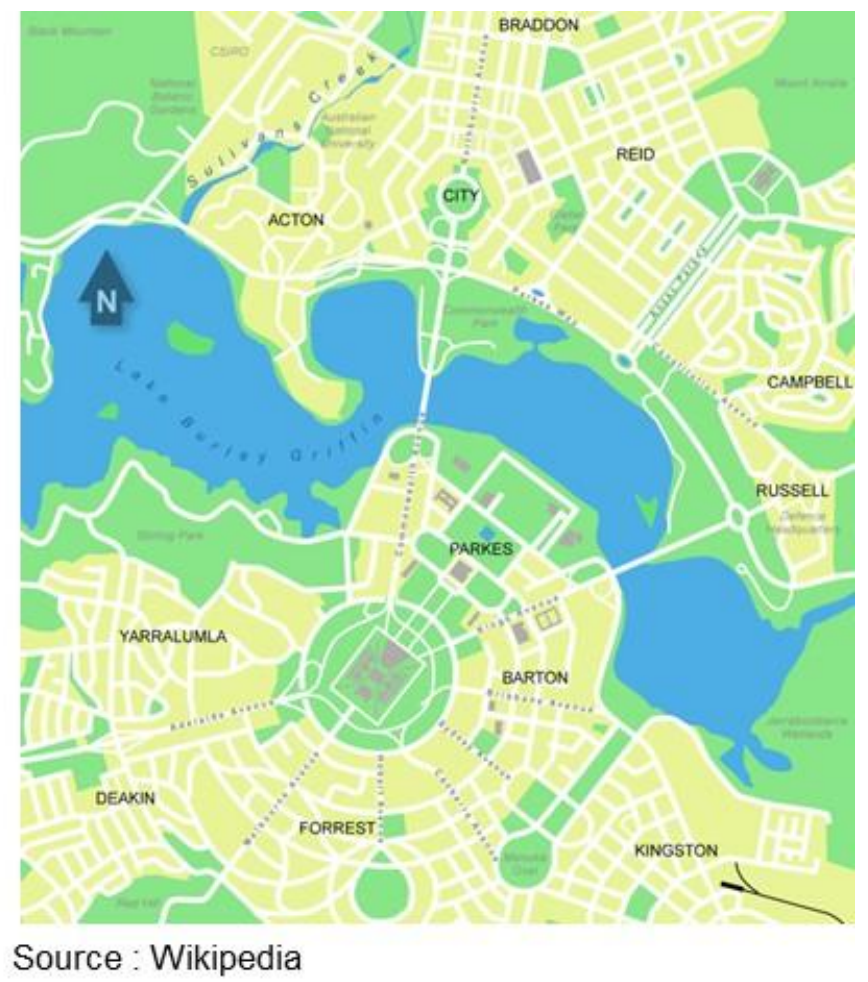

Figure 12. Map of Parliament Triangle

Peripheral Area covers the rest 5 districts. These are Belconnen and Gungahlin in the north, and Woden, Weston Creek, and Tuggeranong in the south. Each district is furnished with Community Facilities, such as commercial facilities, service facilities, the bus terminal in the town center. While the health facilities, education facilities, safety and security facilities, and urban parks are furnished scattered in the districts. Belconnen and Tuggeranong as big districts, each is equipped with the commercial mall (Wikipedia, 2020b). The map of the Town Centers is presented in Figure 13 as follows.
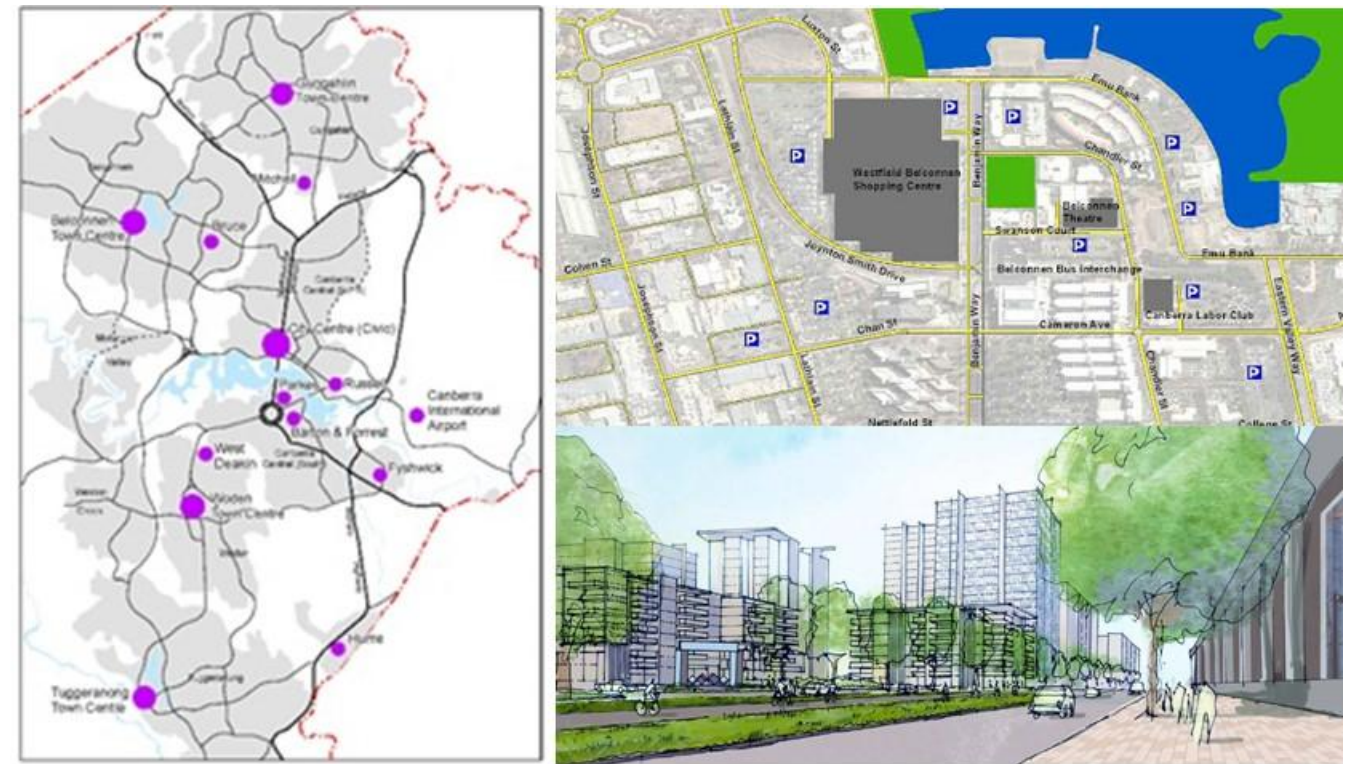

Source : Wikipedia

Figure 13. Map of All Districts Town Center and Belconnen Town Center 
Practically all of important Canberra Landmarks are situated around Parliament Triangle. The most important ones are the Parliament Building, Australian War Memorial, Anzac Parade, and Lake Burley Griffin. These can be seen clearly from the Mount Ainslie Look Out Point and it became the most seen view of Canberra (Wikipedia, 2020b) This view is presented in Figure 14.

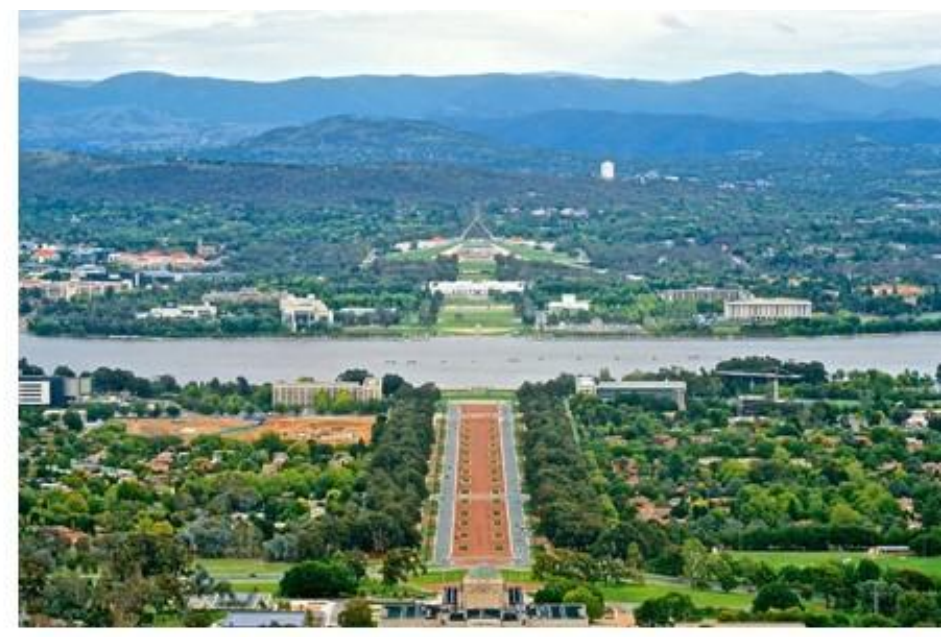

Source : Wikipedia

Figure 14. Canberra View from Mount Ainslie Look Out Point

Open Space \& Green Parks can be enumerated into 5 groups, i.e. Lake Griffin, the Anzac Parade, Botanical Garden, Nature Reserve, and Urban Parks. Lake Griffin is an artificial lake as a centerpiece of Canberra. To create the lake on Molonglo River, Scrivener Dam was constructed in the west downstream. Following the natural topography, the dam has a tortoise form, which can be divided into 3 parts, i.e. East Lake, Central Lake, and West Lake. It has an area of $6.64 \mathrm{sqkm}, 11 \mathrm{~km}$ length, and max-width of $1.2 \mathrm{~km}$. It has an average depth of $4 \mathrm{~m}$, and a water volume of $33,000,000 \mathrm{~m}^{3}$. The Anzac Parade is a significant large boulevard in front of the Australian War Memorial. Stretching of $1.1 \mathrm{~km}$, it is often used for Military Ceremonial Parade. The Australian National Botanical Garden (ANBG) is located at Acton, North Canberra, in the foot of Black Mountain east of ANU. It was established in 1949. The 33 of Nature Reserves, scatter, cover area of 90 ha, and are grouped into Canberra Nature Park. Nature Reserve varies from hills, grasslands, bushes, river corridors, wetlands, and others. Examples of Nature Reserves are Black Mountain, Mountain Ainslie, Jerrabombera Wetland, Red Hill, Aranda Bushland, Molonglo River Corridor, Jerrabombera East Grassland, etc. Canberra also has 26 Urban Parks. These are all kinds of parks, smaller than Nature Park, and are grouped as town parks, district parks, and neighborhood parks. Examples of these are Aston Park (10.4 ha), City Hill (5 ha), etc. Canberra is a very green city, it has abundant of nature reserves and urban parks (Wikipedia, 2020o; Wikipedia, 2020p). The Location Map of Nature Reserve and Example of Nature Reserve Photos is presented in Figure15. 


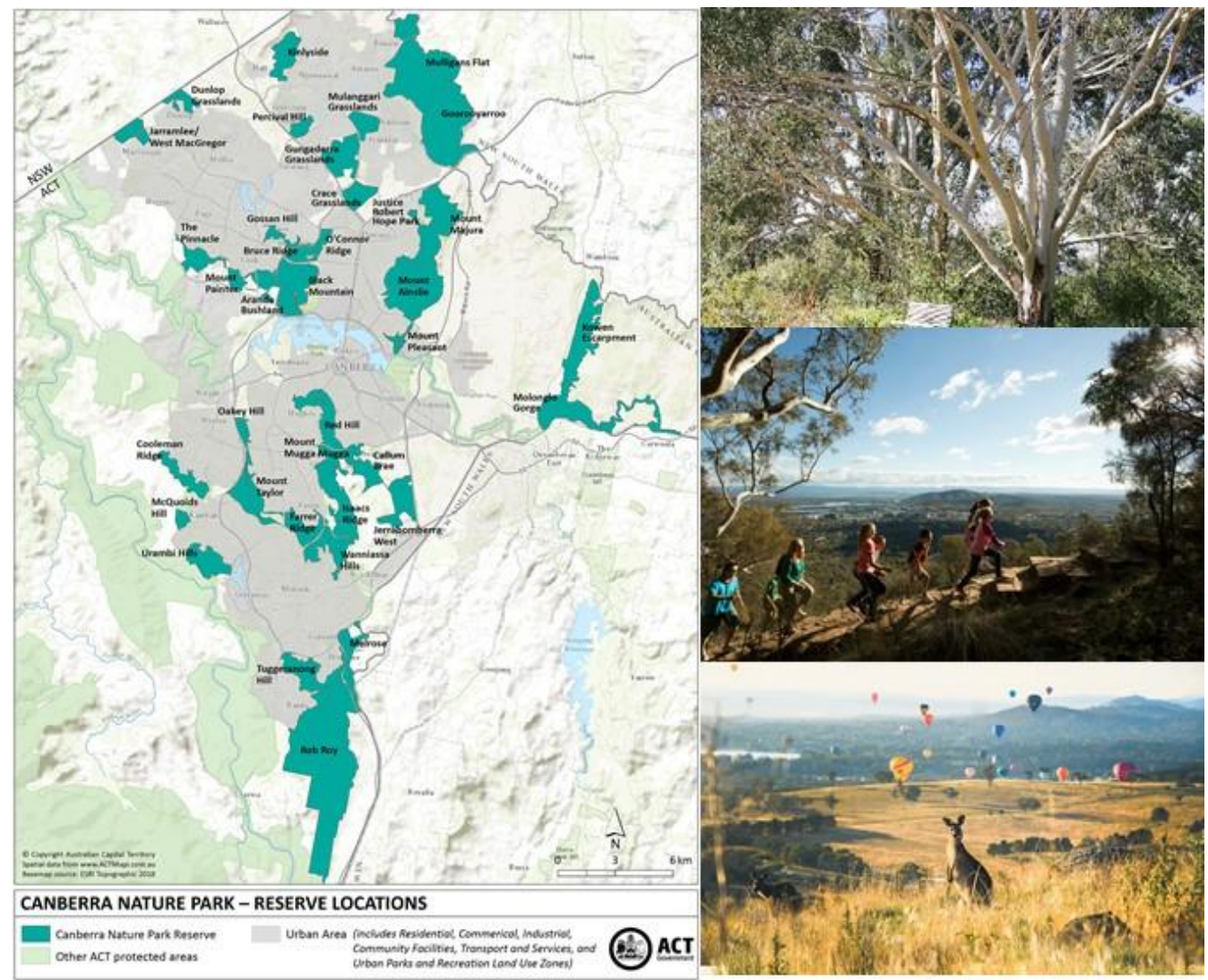

Source : Wikipedia

Figure 15. Location Map of Nature Reserves and Example of Photos

Canberra is also furnished with Cultural Center and Scientific Center of national importance. These important Centers are Australian War Memorial (AWM), Museum of Australian Democracy (MAD), Questacon National Science and Technology Center (NSTC), National Gallery of Australia (NGA), National Portrait Gallery (NPG), National Museum of Australia (NMA), National Film and Sound Archive of Australia (NFSAA), Gallery of Australia Design (GAD). The pertinent Scientific Center are National Library (NL), Geoscience Australia (GA), National Archives of Australia (NAA), National Dinosaurus Museum (NDM).

Canberra also has a function to seat the center of national important higher education. Military institutions in Canberra consist of the Royal Military Academy Duntroon and Australia Defence Force Academy. Canberra is home for Australia National University (ANU), University of Canberra (UC), Canberra Institut of Technology (CIT), and recent University of New South Wales (UNSW), Australian Institute of Sports (AIS), and the others.

The location map of Canberra's national important Cultural Centers, Art Centers, Scientific Centers, and Universities is presented in Figure 16. 


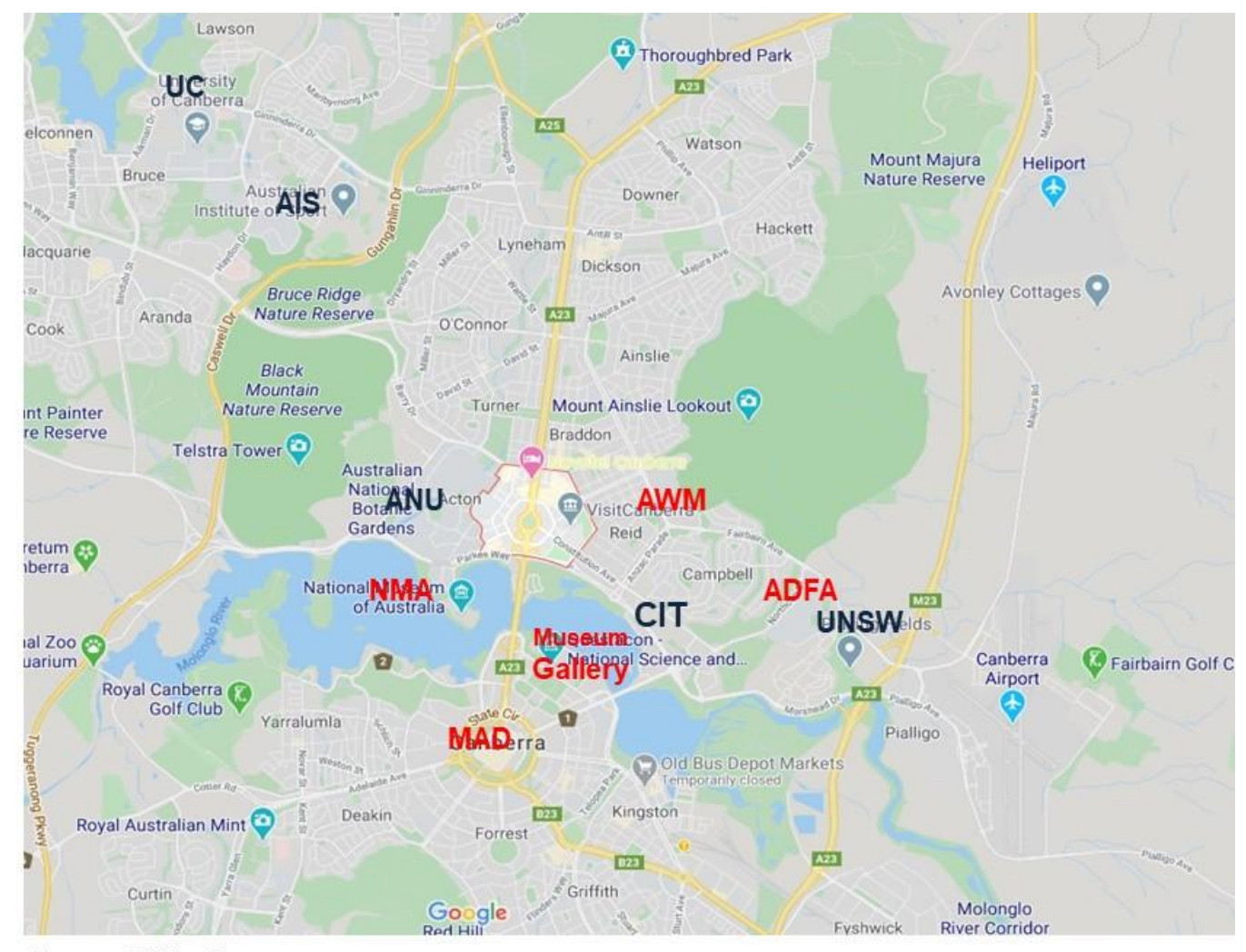

Source : Wikipedia

Figure 16. Location Map of Cultural Centers, Scientific Centers, and Universities

Transportation review is divided into two parties, i.e. the national \& international transportation, and urban transportation. International transportation is served by air transportation by Canberra International Airport (CIA). The airport is located on the northwestern tip of the South Canberra district. The national transportations are served by road transportation, railway transportation, and air transport. The train station is located in Kingston, in South Canberra. The CIA has good domestics connections to the 6 Australian State's capital. Meanwhile, the urban movements are served mainly by road transportation and railway transportation recently. Canberra has a well-structured road network, classified into Parkway, National Arterial Road Network, Collector, and Local Road Network. Tuggeranong Parkway is a good example of Parkway in Canberra. The road public transport is served by the city bus and taxi. Each town center in every district is equipped by the bus terminal, either big enough or small one. It depends on the importance of the town center. Belconnen and Tuggeranong town center, for example, is furnished with an important city bus terminal. Taxi stands are spread all over. Light Rail Train has been operated recently. It is still being developed. The map of Canberra transportation facilities is presented in Figure 17 as follows. 


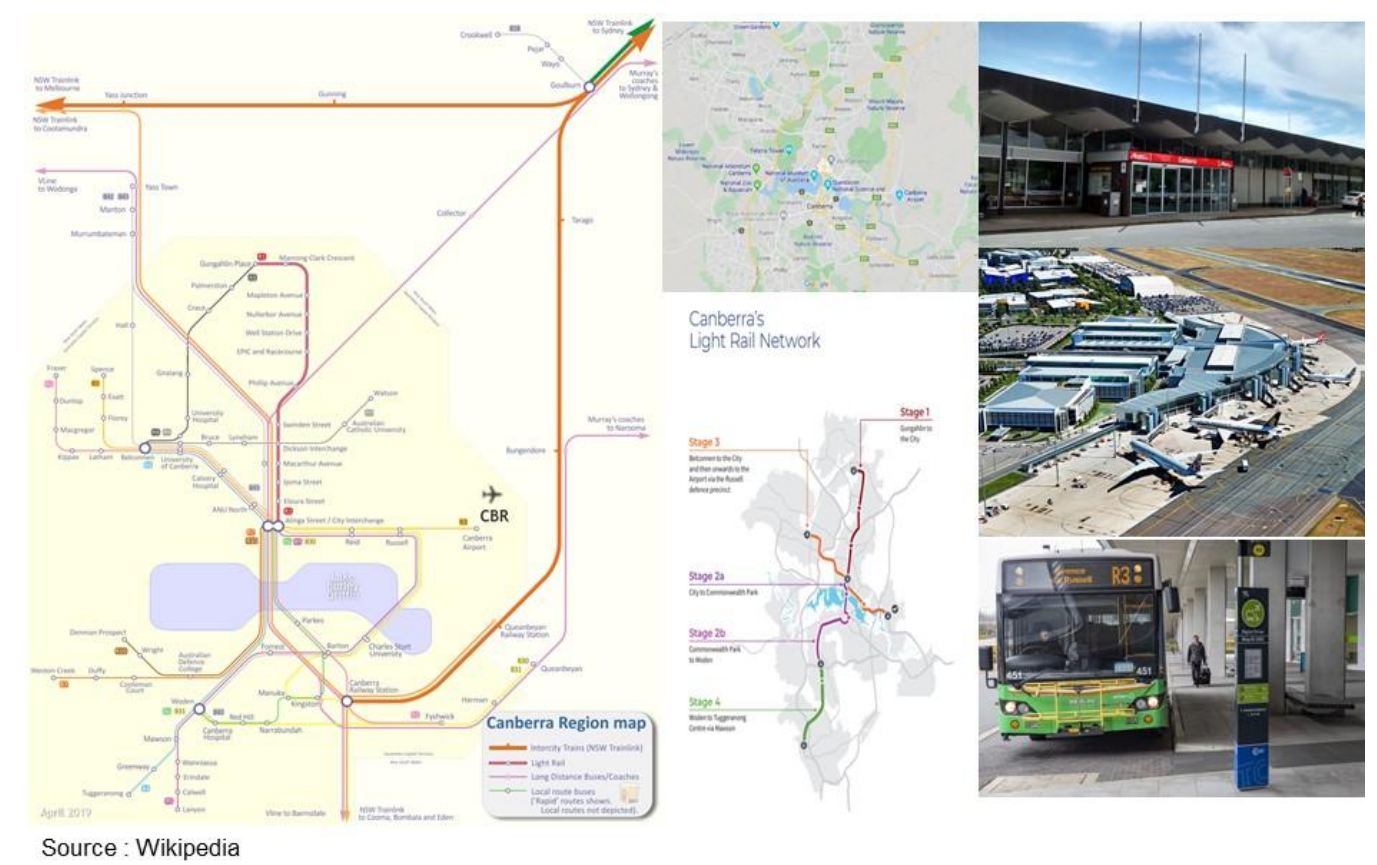

Figure 17. Transportation Illustration of Canberra

\section{The Development}

Canberra was developed in several decennaries. The whole creation and development were started in 1908, with the instauration of the Seat of Government Act in 1908. The construction was started in 1913. It was after the formal approval of the Master Plan on 10 Jan 1913, developed by Walter Burley Griffin. In 1913, W.B. Griffin was appointed as Federal Capital Territory Director of Design and Construction. On 23 Feb 1913, the Prime Minister drove the first peg of construction, and on 12 March 1913 Lady Denman proclaimed the name of the city as Canberra.

Canberra was developed step by step. The Royal Military College was opened in 1911. The Provisional Parliament House was started to be used on 9 May 1927. During the early years, Government Office a bit slow to be finished, people were reluctant to move to Canberra due to a lack of facilities. The Australian War Memorial was finished in 1941. Lake Burley Griffin was finished in 1964. Prompted by the development of Parliament Triangle as following Griffin's idea. The various buildings of national importance were started to be built in the front lake. Population increase approximately by 50\% each year, in 1965-1975. It is indicated the maturity of Canberra as the National Capital City.

\section{The Important Notes}

Some important notes on Canberra spatial plan are presented as follows. Canberra is planned and developed as Federal Capital City and a city in the garden. Canberra is located in Australia Capital Territory, consisting of Namadgi National Park and Canberra. Namadgi National Park will ensure the water supply for Canberra. In general, Canberra is divided into the Core Area and Peripheral Area with an abundance of Open Space and Green Space. The Open Space is formed by Lake Burley Griffin. While the Green Space, mainly consists of ANBG, Nature Reserve, Urban Park. The Core Area is designated to accommodate the Federal Parliament, the Federal Government Offices, the High Court, the Museum, the Cultural Galleries, and Scientific Centers, and Green Spaces. The Peripheral Area, consists of 5 districts, are designated principally for the residential area. Each peripheral district is furnished with community infrastructure and facilities. Each peripheral district is equipped with a town center. Transportation is served by air, rail, road, and urban transportation. 


\section{Washington DC (USA)}

\section{The Creation}

The American Independence War happened in the years between 1775-1783. During the early year of the war, the 13 colony territories and the provinces of Great Britain declare Independence on 4 July 1776, during the Second Continental Congress meeting, at the Pennsylvania State House (Independence Hall, now), in Philadelphia. The seat of the Federal Government was of-course in Philadelphia. (Wikipedia, 2020c; Wikipedia, 2020d).

In July 1790, the First United States Congress issue an Act for Establishing the Temporary and Permanent Seat of the Government of the United States, well known as the Residence Act. It is stated that the Capital must be used starting in the year 1800. A committee for developing the Capital was formed. Pierre Charles L'Enfant is commissioned to develop the Master Plan. The process of development took a long time. Finally, in November 1800, President John Adams started to live in the Presidential Mansion, in Washington. In 1801, the Congress issue the District of Columbia Act, declaring that District of Columbia is a Federal Territory for the seat the USA Government (Underwood \& Underwood, 2014; Wikipedia, 2020c; Wikipedia, 2020e).

It was decreed in a square area of $16 \mathrm{~km} \times 16 \mathrm{~km}$, across the Potomac River, between Georgetown in the north and Alexandria in the south, covering the tributary of Anacostia River to the Potomac River. Later on, the Virginia area: Arlington county, an area east of Potomac River, was not included in the DC. Finally, Washington DC has an area of $177 \mathrm{~km}^{2}$, with many inhabitants of 705,749 in 2019, the density is 3,987 people $/ \mathrm{km}^{2}$ (Wikipedia, 2020c).

The location map and area map of the Washington District of Columbia is presented in the following Figure 18.

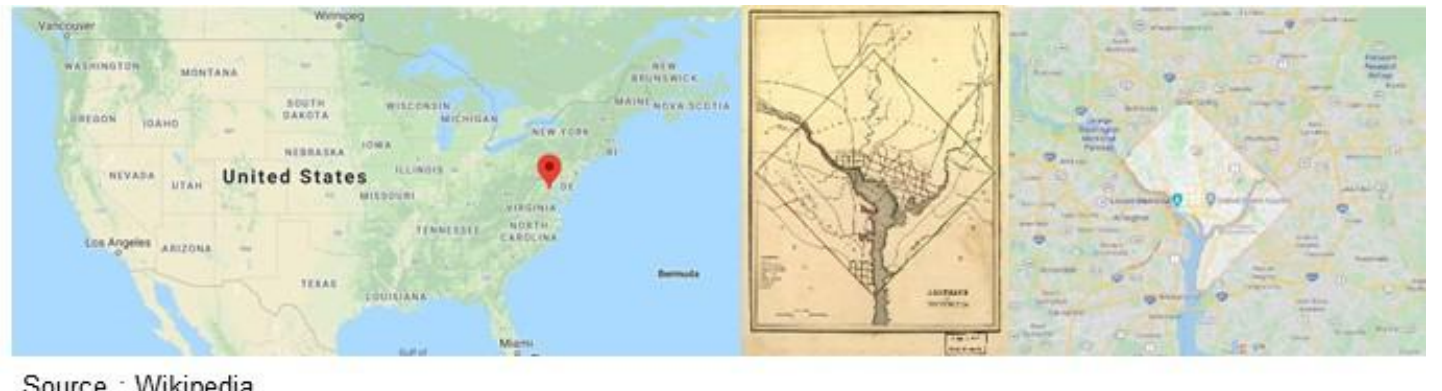

Source : Wikipedia

Figure 18. Washington DC Location Map, Original Area Map, and Existing Area Map

The City Main Function and Activity

As it is mentioned in the Residence Act and District of Columbia Organic Act, Washington DC is established and developed as Federal Territory for the seat of USA Federal Body. It is designated to represent and the center of the nation. The main function is to accommodate the legislative body, the executive body, and the judicative body, the diplomatic institution, and certain important international organizations. It must capable to represent the national culture and must capable to accommodate the world's important cultural representation (Wikipedia, 2020e; Wikipedia, 2020f). The city must be equipped with the needs of the daily basic needs of its population, such as education, healthcare, leisure, sports facilities, groceries, market, mall, etc. Even if, there are no top American universities located here, it must be noted the existence of a dozen colleges, and the Georgetown University, who get the $29^{\text {th }}$ in American Universities Ranking. It must be equipped also with good basic urban infrastructure and facilities. As the capital, the city must be well protected for safety and security. The city also must be in good green condition. There are dozens of National Parks in Washington DC, and a lot of Circles and Squares are assigned as city gardens (Wikipedia, 2020c). Seven traditional Washington DC economic sectors are federal government \& contractors, professional services, 
technology, hospitality, retail, education \& healthcare, real estate \& construction. Big and heavy industrial activity is prohibited (OMDC, 2012).

\section{The Spatial Plan}

The Spatial Plan of Washington DC can be regarded this way. The city is centered in the National Mall as the seat of the city's main function bodies, extended to the surrounding area by a particular road network. The road network is a very regular perpendicular road network grid north-south-wise and east-west-wise, crisscrossed by non-perpendicular wide avenues. The big junctions are constructed in the form of a circle or square. Certain blocks here and there are designated to be city gardens, apart from the existence of some national parks Building height is regulated by the Height Act. The city plans practically still the same as the original plan, drawn by Pierre Charles L'Enfant, in the 1790s. While the National Mall plan has been extended by McMillan Commission in 1901. Regarding the extension of the National Mall and the road width, it can be said that Washington DC is planned for a very long horizon year (Underwood \& Underwood,2014; Wikipedia, 2020c; Wikipedia, 2020f).

The L'Enfant Original City Master Plan and the McMillan Commission Extended National Mall Plan are presented in Figure 19, as follows.

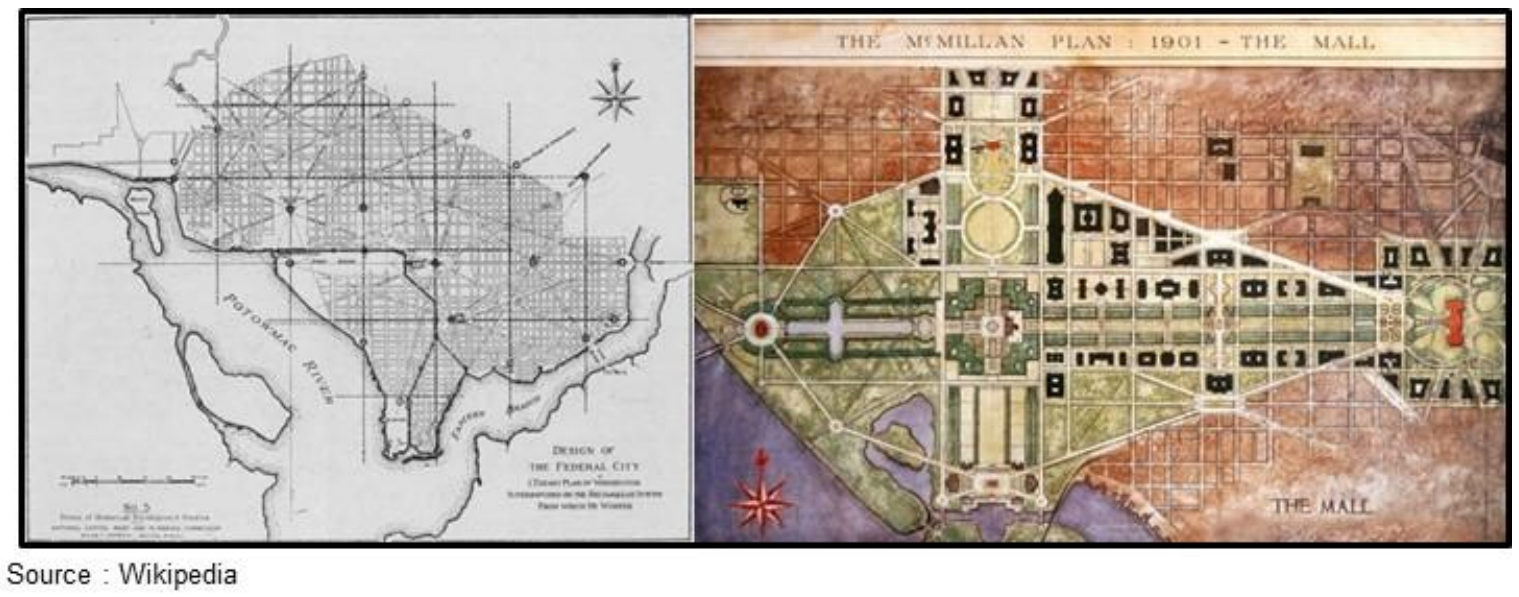

Figure 19. L'Enfant Plan of Washington and McMillan Commission Plan of National Mall

Washington DC, administratively, is divided into 8 wards and each ward is divided into several neighborhoods. Each ward has a representative in the City Council (Wikipedia, 2020c; Wikipedia, 2020g). The map of wards and neighborhoods division is presented in Figure 20 as follows.
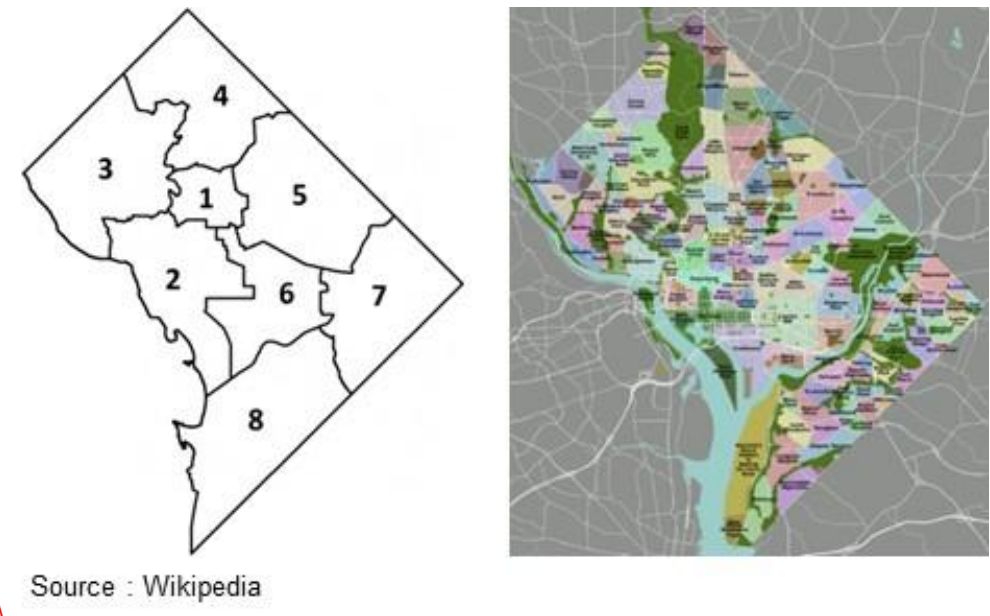

Figure 20. Wards and Neighborhoods of Washington DC 
National Mall is a very vast open space cross, of $3 \mathrm{~km}$ length in the east-west direction, with $463 \mathrm{~m}$ wide. The three main Federal Bodies buildings, i.e. the Capitol, the White House, and the Supreme Court, are located in the National Mall area. All of 13 Federal Department main buildings are located in the vicinity of the National Mall: in Constitution Ave, Independence Ave, Pennsylvania Ave, Vermont Ave, New Jersey Ave. The Department of Homeland Security is located a bit far away in the northwest of the National Mall in Nebraska Avenue. The Department of Defense is located on the other side of Potomac River, the Pentagon building, in Arlington County, Virginia. The National Mall is also filled with cultural building, i.e. national museum, national art gallery, Smithsonian building and museum, art building, performing arts building, and national monuments: George Washington Memorial, Lincoln Memorial, Thomas Jefferson Memorial, Vietnam War Memorial, etc (Wikipedia, 2020c; Wikipedia, 2020f)

The area, surrounding the National Mall is considered as the Downtown of Washington DC. The downtown cover most of the Ward 2 area. The rest of this downtown area is occupied by a mix between the office area, commercial area, education area, and the residential area (Underwood \& Underwood, 2014; Wikipedia, 2020f).

A bird view photo of the National Mall is presented in Figure 7. The photo face westward. It clearly shows the Capitol, the National Library of Congress, the Supreme Court, and the George Washington Memorial, an obelisk in far away. The White House can not be seen, it is directly located at the intersection between the greenery mall right of the Washington Memorial and Pennsylvania Avenue. The Pennsylvania Avenue is a wide avenue stretched in the westnorth direction from the Capitol (Wikipedia, 2020c; Wikipedia, 2020f). Aerial View of the National Mall is presented in Figure 21.

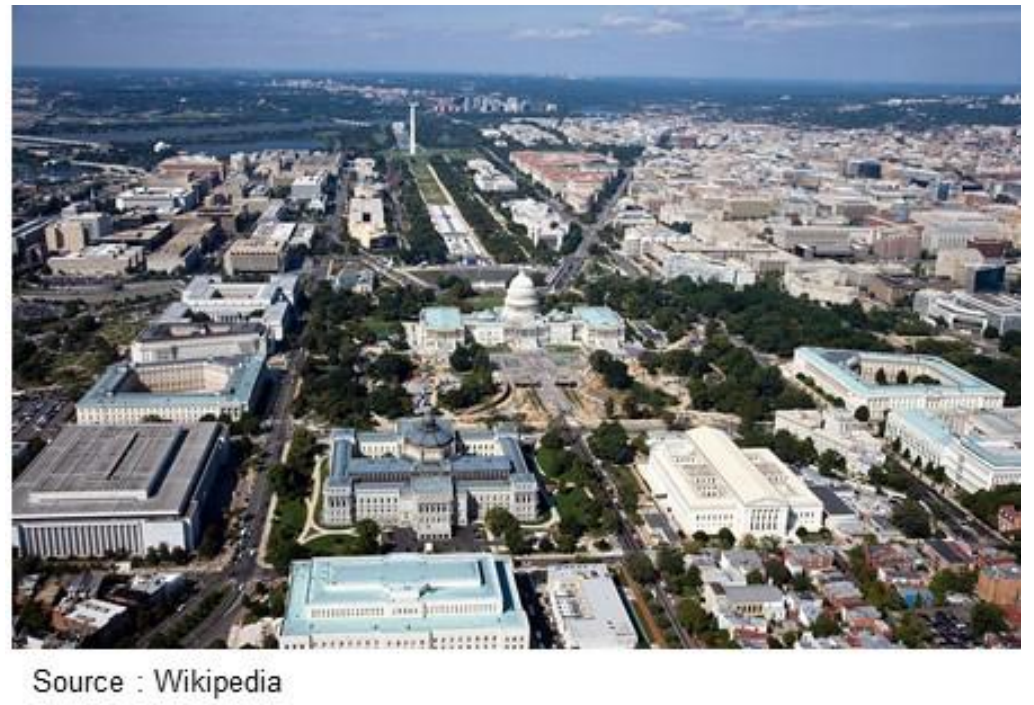

Figure 21. A Bird View of the National Mall

Apart from the downtown around the National Mall, in Ward 2, the whole Washington DC density is controlled by Height Act. Activity distribution is controlled, by controlling landuse. Embassy complex is located around DuPont Circle. On the north side of the Anacostia River, we can find several Navy Base. A residential area dominated area far from the downtown (NCPC, 2012; Tanya, 2019; Wikipedia, 2020c).

The city also must be in good green condition. The green is provided by dozen of National Parks and a lot of greened circles, squares, plazas, and blocks. Among the dozen, these 5 parks are the most well-known well, i.e. Rock Creek Park, National Mall, Kenilworth Park \& Aquatic Garden, Georgetown Waterfront Park, Anacostia Park, Fort DuPont Park. Washington DC has 3 main water bodies, i.e. Potomac River, Anacostia River, and Tidal Lake, apart from several 
creeks and canals (Wikipedia, 2020c; Wikipedia, 2020e). Location Map of the National Parks is given in Figure 22, as follows.

Most of the universities are located in the North West area of Washington DC. The Georgetown University (GU) is located in Georgetown closed to Alexandria Aqueduct. The George Washington University (GWU) is located close to Washington Circle, in between Pennsylvania Avenue and Virginia Avenue. The American University (AU) is located in the corner of the intersection between Massachusetts Avenue and Nebraska Avenue. While, the Howard University (HU) is located in Bloomingdale Area, between Georgia Avenue and McMillan Reservoir (Jeffreyn, 2005; Tanya, 2019; Wikipedia, 2020c). Location Map of the 4 Important Universities is presented in Figure 22.

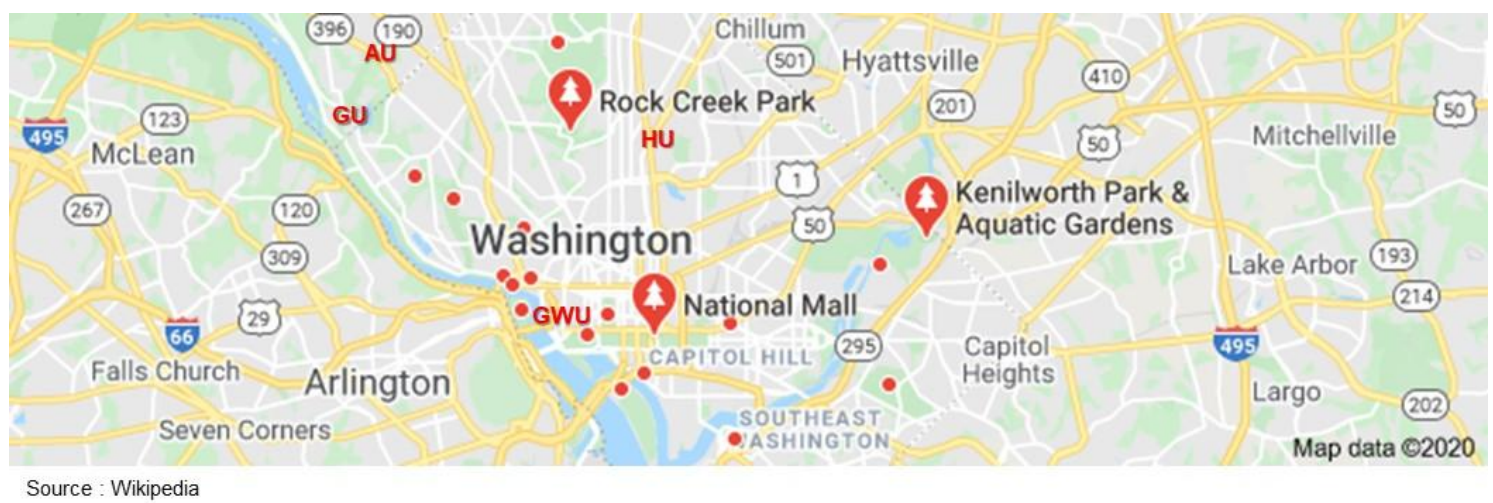

Figure 22. The National Parks and the 4 Important Universities in Washington DC

The Washington DC area is covered by the road network, very wide avenues, and certain expressway stretching along the west bank of the Potomac River and in the south of the Jefferson Memorial across the city south of National Mall to reach the intersection closed to the Pennsylvania bridge. From here two directions to the south and the west crossing the city west of the Capitol Hill. Urban public transport is served by the Washington DC bus and the Washington Metropolitan Metro (Wikipedia,2020c).

The Washington Metropolitan has a ring road of freeway crossed by several diagonal freeways. While public transport is served by city bus and metro. Connection with exterior connected by railway with union Railway Station and two airports: Dulles International Airport and Ronald Reagan Domestic Airport (Wikipedia, 2020c). The transportation infrastructure network is presented in Figure 23 as follows.
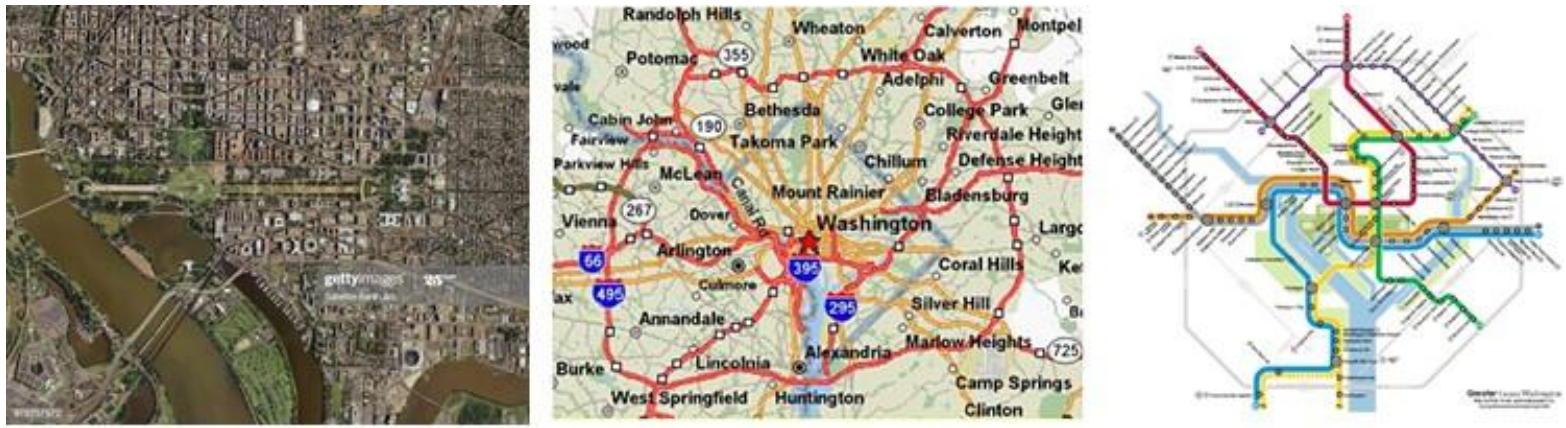

Source : Wikipedia

Figure 23. Main Road Network Plan and Metro Plan of Washington DC Metropolitan

As a federal capital, Washington DC is furnished with an Arlington National Cemetery. The Department of Defense center for orchestrating the defense is located in Pentagon Building, in Arlington County, Virginia, just east of Washington DC, on the other side of the Potomac River. For capital protection against aggression a major Joint Military Base Andrew is located south of Washington DC (Stern, 2019; Wikipedia, 2020c). 


\section{The Development}

The Washington DC development was executed very step-by-step. It was started by activated of the Residence Act in 1790, establishing the need of the Federal Capital in $10 \times 10$ sq.mil of area $\left(16 \times 16 \mathrm{~km}^{2}\right)$, on Potomac River between Alexandria and Georgetown, and had to be used in 1800. In March 1792 first Washington City Plan was created, and on 1 January 1793, the Commission reported that the DC boundary is finished. In 1800 President Mansion has been finished, and in November 1800 John Adams as the President moved to President Mansion. The National Mall was still empty and was not yet built at all (See Figure 8). The Capitol development was started in 1814 and finished in the 1860s (see Figure 9). In 1835, a rail line from Baltimore, Baltimore \& Ohio Railway Company, reached Washington. In 1851, B\&O large station was finished in New Jersey Avenue, just on National Mall. In 1901 National Mall was extended. In 1907, Union Station has been built, and the B\&O station has been demolished. There is no longer a train station next to the National Mall (Jeffreyn, 2005; Wikipedia, 2020c; Wikipedia, 2020f, Wikipedia, 2020g). View of the National Mall in 1814, 1830, 1860, 1914, and 1940, are presented in Figure 24, Figure 25, and Figure 26 as follows.

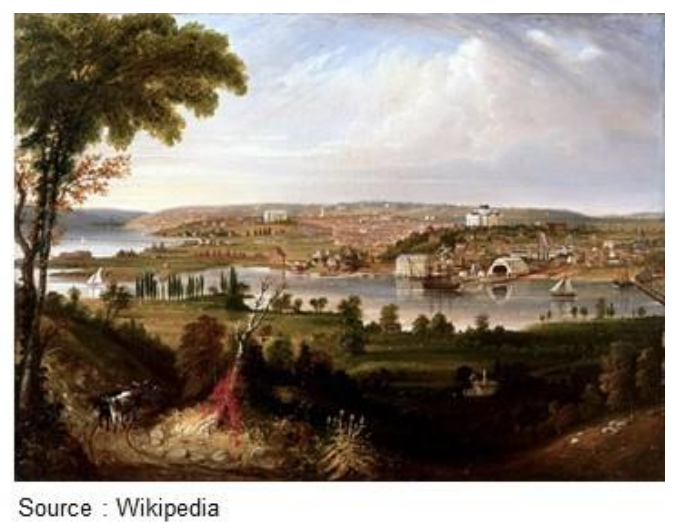

Figure 24. View of the White House and the Capitol from beyond the Navy Yard in 1830

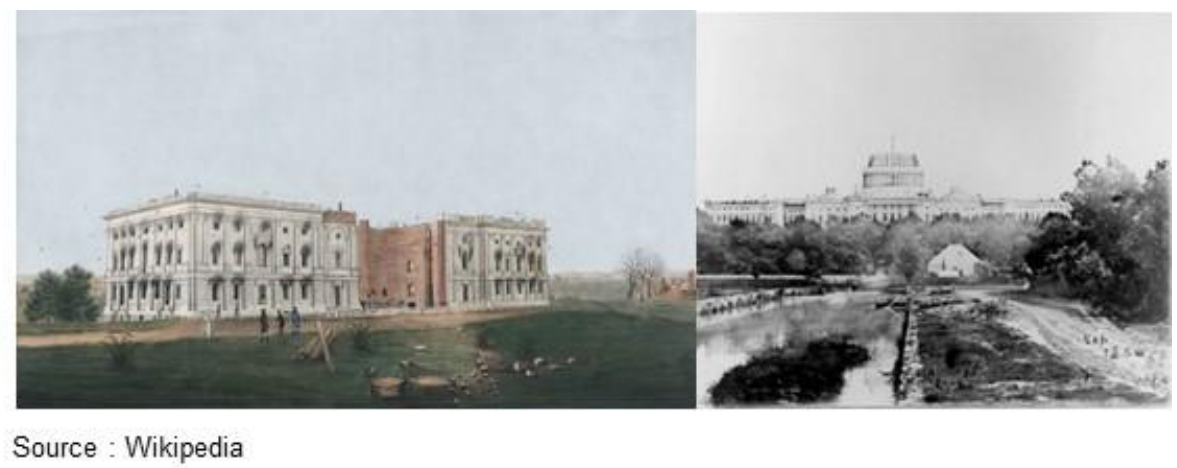

Figure 25. The Capitol in circa 1814 started to be constructed and in 1860 under construction
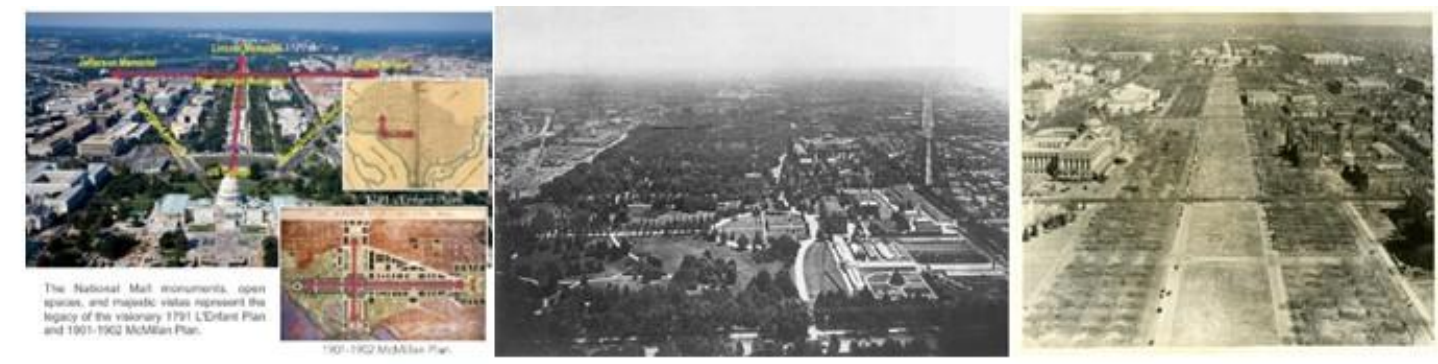

Source : Wikipedia

Figure 26. The National Mall Extension Plan, the 1901 condition, and the 1940 condition 


\section{The Important Notes}

Several important facts, related to the Washington DC spatial plan, have to be noted here. Washington DC has been purpose-built on an empty area. The spatial plan was referred to several modern European capital cities, with a far-future horizon year plan. The road network plan is very practical, very American style, a perpendicular north-south east-west grid, crossed by non-perpendicular big avenues as arterial urban roads. A National Mall is planned as the city center, the center of interest, symbolic center, in which the three main national bodies are located: the legislative, the executive, and the judicative. Cultural centers are located along the National Mall. Building heights are also regulated, to control the cityscape, city density, and in some extent environmental condition. The city is equipped with diplomatic facilities and places for international organization headquarters. Military bases are developed in the surrounding area to protect the capital from any invasion. Green areas are very well organized. No industries, heavy industries are prohibited in Washington DC and the surrounding area. The basic master plan was developed step by step afterward.

\section{CONCLUSION}

The objective of this research has been well achieved. Several main conclusions can be drawn as follows.

- All of the three capitals are planned and built from zero to an inhabited area.

- Well planned, well organized, and well-controlled.

- It is better furnished by a National Park.

- Development at least takes several years, even maybe decencies.

- A Master Plan with long future horizon year, and developed step-by-step.

- The city is planned and developed with strong symbolic and environmental preservation aspects.

- The city in general, consists of Center Area, Pheriperal Area, and OpenSpace \& Green Area.

- The Center Area is to accommodate the national important offices, diplomacy offices, symbolic facilities.

- Peripheral Zone is for residential areas and community facilities. It is divided into several communities: districts/suburbs/precincts.

- Open Space is formed by a water body, a wide stripe of open space.

- The Green Area consists of Natural Park, Nature Reserve, Urban Park. These must be interconnected with green stripes. Land with a more than certain height must be preserved as Nature Reserves

- Having a good domestic and international connection.

- Having a well-structured road network and Public Transport.

This work-induced several curiosities and ideas of works, such as to observe a well planned and controlled capital city with good infrastructures and facilities, to develop the basic principle of urban infrastructure \& facility system, to observe the failure of capital cities, to observe more in-depth several important purpose-built capitals, to observe the legal aspects and main regulations, to observe the institutional aspects, to observe the economic and financial aspects, to observe the development and construction step, to observe the city management institution, to observe the green aspects, to observe the intelligent city aspect, etc.

Notes. This paper is a reflection collaboration among Civil Engineer from Institut Teknologi Sepuluh Nopember (ITS) - Indonesia, an Architect from Universiti Teuku Abdul Rahman (UTAR) - Malaysia, and an Urban Planner from Universitas Gajah Mada (UGM) - Indonesia. This is part of Working Papers to develop the Infrastructure \& Facility Asset Management knowledge and science. Hopefully, there will be other authors who have a willingness to donate their reflection on Capital Relocation, as papers for JIFAM. 


\section{REFERENCES}

Abd Manan, Abd Muluk \& Suprayitno, Hitapriya (2020). "Preliminary Overview of Several Capital Relocations in Relationship with a Plan of Indonesian Capital Relocation". Journal of Infrastructure \& Facility Asset Management, 2(1) March 2020.

Asmara, Chandra Gian (2019). "Ibu Kota Pindah ke Kaltim, Ini Pernyataan Lengkap Jokowi": CNBC Indonesia, 29 Agustus 2019, 14:03.

Fugate, Jeffreyn (2005). "City Study: Washington DC". MIT Workshop on City Form, Fall 2005.

Kaur, Dashveenjit (2019). The journey of Putrajaya - Malaysia's jewel capital. The Malaysian Reserve, Thursday, 31 January 2019.

Moser, Sarah (2010). Putrajaya: Malaysia's New Federal Administrative New Capital. Cities, 27 (2010) 285-297.

NCPC (2013). Height Master Plan Study for Washington, DC. Information Session, September 25, 2013. National Capital Planning Commission.

OMDC (2012). The Five-Year Economic Development Strategy for the District of Columbia. Executive Summary. Office of Vincent c. Gray - The District of Columbia, November 14, 2012.

Ho, Chin Siong (2006). Putrajaya Administrative Center of Malaysia: Planning Concept and Implementation. Sustainable Urban Development and Governance Conference, 16 November 2006. Sung Kyun Kwan University. Seoul. Korea.

Ho, Chin Siong (2006a). Lessons Learned from Planning of Putrajaya City - Administrative Center of Malaysia. Seminar UTM-SIT Workshop at Shibaura Institute Japan on 14 December 2006.

Nor, Gani Md. \& Nor, Abd Rahim d. (2006). Predicting the Impact of Demand and Supply Side Measures on Bus Ridership in Putrajaya, Malaysia. Journal of Public Transportation, Vol. 8, No. 5, 2006.

Omar, D.B. (2004). The Total Planning Doctrine and Putrajaya Development. Sustainability III. WIT Press. Southampton.

Putrajaya Corporation (2012). Putrajaya Low Carbon Green City. Iniative Report. Putrajaya Corporation. Putrajaya. Malysia.

Stern, Tanya (2019). Recent General Plan Updates in the Washington, DC Region. 2019 Winter Speaker Series. Montgomery County Planning Department.

Soemitro, R.A.A. \& Suprayitno, H. (2018). "Pemikiran Awal tentang Prinsip Dasar Manajemen Aset Fasilitas". Jurnal Manajemen Aset Infrastruktur \& Fasilitas 2(Suplemen 1) Juni 2020.

Suprayitno, H. \& Soemitro, R.A.A. (2018). "Preliminary Reflexion on Basic Principle of Infrastructure Asset Management”. Jurnal Manajemen Aset Infrastruktur \& Fasilitas, 2(1) March 2020.

Underwood, Carmel \& Underwood, Robert (2014). "The Making of a City”. English Teaching Forum, April 2014.

Wikipedia (2020). "List of purpose-built national capitals". English Wikipedia Org. https://en.wikipedia.org/wiki/List_of_Purpose-built_national_capitals.

Wikipedia (2020a). "Putrajaya". Wikipedia, https://en.wikipedia.org/wiki/Putrajaya.

Wikipedia (2020b). "Canberra". Wikipedia, https://en.wikipedia.org/wiki/Canberra.

Wikipedia (2020c). "Washington DC". Wikipedia. https://en.wikipedia.org/wiki/Washington.

Wikipedia (2020d). "United States Declaration of Independence". English Wikipedia Org. https://en.wikipedia.org/wiki/United_States_Declaration_of_Independence.

Wikipedia (2020e). "Residence Act". Wikipedia. https://en.wikipedia.org/wiki/Residence_Act. Wikipedia (2020f). "National Mall”. Wikipedia. https://en.wikipedia.org/wiki/National_Mall. 
Wikipedia (2020g). "History of Washington DC". English Wikipedia Org. https://en.wikipedia.org/wiki/History_of_Washington_DC.

Wikipedia (2020h). "History of Australia". English Wikipedia Org.. https://en.wikipedia.org/wiki/History of Australia.

Wikipedia (2020i). "History of Canberra". English Wikipedia Org.. https://en.wikipedia.org/wiki/History of Canberra.

Wikipedia (2020j). "Australia Capital Territory". English Wikipedia Org.. https://en.wikipedia.org/wiki/Australia_Capital_Territory.

Wikipedia (2020k). "History of Australia Capital Territory". English Wikipedia Org.. https://en.wikipedia.org/wiki/History_of_Australia_Capital_Territory.

Wikipedia (20201). "Namadgi National Park". English Wikipedia Org.. https://en.wikipedia.org/wiki/Namadgi_National_Park.

Wikipedia (2020m). "Protected Area of Australia Capital Territory". English Wikipedia Org.. https://en.wikipedia.org/wiki/Protected_arae_of_Australia_Capital_Territory.

Wikipedia (2020n). "Suburbs of Canberra". English Wikipedia Org.. https://en.wikipedia.org/wiki/Suburbs of Canberra.

Wikipedia (2020o). "Australian National Botanical Garden". English Wikipedia Org.. https://en.wikipedia.org/wiki/Australian_Natonal_Botanical_Garden.

Wikipedia (2020p). "Canberra Nature Park". English Wikipedia Org.. https://en.wikipedia.org/wiki/anberra_Nature_Park. 